IFN Working Paper No. 919, 2012

\title{
The Dynamics of Offshoring and Institutions
}

Fredrik Heyman and Patrik Gustavsson Tingvall 


\title{
The Dynamics of Offshoring and Institutions
}

\author{
Fredrik Heyman* \\ Patrik Gustavsson Tingvall**
}

\begin{abstract}
Previous research has found that weak institutions can hamper investment and alter patterns of trade. However, little is known about the impact of institutional quality on offshoring. This lack of knowledge is surprising, given that offshoring has become an important part of many firms' internationalization strategies. This study uses detailed firm-level data for the 19972005 period to examine the relationship between institutional quality in 113 source countries and offshoring by Swedish firms. The results suggest that weak institutions are negatively related to offshoring in general and to the offshoring of R\&D- and relationship specificityintensive inputs in particular. An analysis of learning effects suggests that the impact of weak institutions on the offshoring of relationship specificity-intensive inputs vanishes when firms return to countries from which they have previous market experience. Our results are robust to the use of various measures of institutional quality.
\end{abstract}

JEL: F14; F23; P48

Keywords: Offshoring; Institutions; Firm-level data

Acknowledgments: Fredrik Heyman gratefully acknowledges financial support from the Swedish Research Council and the Swedish Research Council for Health and Working Life and Welfare (Forte). Both authors also gratefully acknowledge financial support from the Torsten Söderbergs Research Foundation. We have benefitted from feedback provided by seminar and conference participants at a variety of locations and conferences, from two anonymous referees and from the Editor Christine Zulehner.

* Research Institute of Industrial Economics and Lund University, Sweden, fredrik.heyman@ifn.se.

** Ratio Institute, Sweden and Södertörn University, patrik.tingvall@ratio.se. 


\section{Introduction}

Over the last two decades, the study of institutions has evolved from a marginal topic to a vibrant area of economic research. The bulk of this research focuses on the relationship between institutions and economic growth, but the question of how institutions affect trade and investment is also receiving increased attention. As an indication of the importance of institutions for trade, Anderson and Marcoullier (2002) and Márquez et al. (2010) show that institutions have an even stronger influence than tariffs on international trade.

In this paper, we empirically analyze the relationship between institutional quality in source countries and firm-level offshoring for the 1997-2005 period. Offshoring gives rise to trade in intermediate inputs, implying that inputs that were previously produced in-house are relocated to an agent in a different jurisdiction. As international offshoring may involve the transfer of knowledge and management control, institutional barriers can strongly affect offshoring (Antràs and Helpman, 2006; Grossman and Helpman, 2003, 2005).

Institutional quality not only affects the choice of country and traded volumes in a static manner but also has implications for trade patterns in terms of spell duration and trade flow dynamics. Models based on search costs show that when learning effects related to the contracting partners and market experience arise, the role of institutions becomes muted over time (Raush and Watson, 2003; Aeberhardt et al., 2011; Araujo et al., 2012).

The study of learning effects associated with trade is a growing area of research. Learning effects can be distinguished into two concepts: learning to trade and learning by trading (Alvarez and Lopez, 2005). Learning to trade refers to self-selection into trade (decisions made before trade begins) and concerns the costs incurred before trade begins, such as the costs of gathering information about the target market, making potential product adjustments, and obtaining permits and licenses (Segerstrom and Stepanok, 2012; Dai and Yu, 2012). Learning by trade, however, refers to changes in firm behavior after trade has been initiated and concerns learning about, e.g., rule of law, intellectual property rights, and the contracting partner. Both types of learning can be influenced by institutional quality.

Despite the central role that institutions play in offshoring, empirical evidence documenting their role remains scarce. ${ }^{1}$ One exception is Niccolini (2007), who studies the

\footnotetext{
${ }^{1}$ In contrast with the literature on institutions and offshoring, the empirical literature on institutions and FDI is relatively large. Many of these studies use measures of perceived corruption to reflect institutional quality
} 
impact of institutions on trade between US firms and their foreign affiliates (in-house offshoring). Niccolini (2007) finds that weak institutions hamper trade in intermediate goods but that the impact of such institutions on the final consumption of goods is less clear. ${ }^{2}$

One explanation for the lack of empirical evidence regarding the relationship between offshoring and institutions relates to the difficulty of measuring offshoring. However, a series of empirical papers, many of which focus on the industry or country level, analyze the relationship between institutions and trade. For instance, Anderson and Marcouiller (2002) and Ranjan and Lee (2007) find that institutions affect bilateral trade flows. Turrini and van Ypersele (2010) find that differences between legal systems affect trade. Méon and Sekkat (2006) show that corruption, rule of law, government effectiveness, and a lack of political violence are positively correlated with manufactured goods exports. For the US, Depken and Sonara (2005) find that US exports are positively correlated with economic freedom in the rest of the world. Finally, focusing on learning and dynamic effects, Aeberhardt et al. (2011), Araujo et al. (2012), and Söderlund and Tingvall (2014) find that improved institutions increase the survival rate of export flows and affect the evolution of trade volumes.

As indicated above, the literature analyzing the relationship between institutional quality and international trade is growing, but some research gaps remain. The present study adds to this stream of literature in several ways. First, by explicitly focusing on institutions and offshoring, we analyze a relationship that has received limited attention in the empirical literature.

Second, most previous studies have focused on one or a few institutional variables, such as rule of law, freedom to trade internationally, or corruption. Although these variables are correlated with offshoring, we show that the impact of different institutional variables can differ and thus lead to different conclusions, depending on the measure of institutional quality being used. We argue that to deepen our understanding of institutions, we should first consider the impact of many institutional measures and then attempt to

(Mocan, 2004; Abramo, 2008; Caetano and Calerio, 2005). Other studies on FDI and corruption/institutions include Habib and Zurawicki (2002), Egger and Winner (2006), and Hakkala et al. (2008), all of which find that corruption is detrimental to FDI. Acknowledging that corruption can be considered a general index of institutional quality, evidence suggests that weak institutions (e.g., those with a corrupt environment) hamper ingoing FDI.

${ }^{2}$ Given that the contract costs of negotiating with an external supplier are higher than those of negotiating with an agent internal to a corporation, these results are suggestive, but they may not fully capture the impact of crossborder contract costs. 
disentangle their differential effects. Thus, we analyze 17 different institutional variables covering 113 countries. Additionally, we apply factor analysis to uncover the underlying structure of our large set of institutional variables.

Third, research on how the impact of institutions on offshoring differs across sectors is absent from the literature. To fill this gap, we analyze whether sensitivity to institutional quality differs with respect to the $R \& D$ intensity of different firms and the contract intensity of offshored inputs. Studying the relationship between institutions and offshoring along these dimensions allows us to consider firm heterogeneity and sectoral differences.

Fourth, the question of how learning from past experience affects the duration of offshoring relations remains unexplored. We therefore examine this issue and analyze how the institutional quality of a target economy affects source country selection and offshoring spell duration. To analyze learning effects, we study firms that reenter a market from which they have previously sourced inputs and the effect of previous market experience on selection sensitivity to institutional quality.

Finally, our analysis is based on detailed firm-level data combined with countrylevel data — data that are rarely used in the related literature. These data allow us to apply several econometric approaches to limit the risk that our results may be biased by our choice of econometric method.

The results suggest that a positive relationship exists between institutional quality and firm-level offshoring. We also present evidence on sector and firm heterogeneity with regard to the impact of weak institutions. Regardless of the econometric specification that is used and the type of institution that is analyzed, we find that R\&D-intensive firms are relatively sensitive to institutional quality in target economies. In contrast, this relationship is much weaker for firms in industries with low R\&D expenditures. Similar results are obtained when we consider the R\&D intensity of inputs.

When analyzing offshoring spells of different durations and repeated offshorers, we find that firms that are relatively sensitive to weak institutions dominate long-term relationships. Finally, we present evidence of institutional learning in the sense that offshorers that previously offshored from a specific market become less dependent on institutional quality when they return to the same source market. 
The paper is organized as follows. Definitions and the theoretical link between offshoring and institutions are presented in Section 2; our empirical approach, along with a discussion of key econometric considerations, is presented in Section 3. Section 4 describes the data and presents descriptive statistics. Our results are presented in Section 5, and concluding remarks are provided in Section 6.

\section{Offshoring and Institutions: Concepts and Theory}

\section{How to measure offshoring}

Hijzen (2005) documents different measures of outsourcing and concludes that two approaches dominate the empirical literature. The first measure, formulated by Hummels, Rapoport, and Yi (1998) and Hummels, Ishii, and Yi (2001), focuses on the foreign content of trade. The second measure, originally developed by Feenstra and Hanson (1996), focuses on the foreign content of domestic production by accounting for the share of imported intermediate inputs in production. As data that would allow for the direct measurement of offshoring at the firm level are scarce, this measure of offshoring is often calculated by using an input-output matrix.

One study that aims to measure offshoring at the firm level is Niccolini (2007), who identifies offshoring in the form of cross-border intra-firm trade. One disadvantage of this approach, however, is that it does not capture offshoring to agents external to the firm. Other measures of offshoring include imports broken down by geographical source and product category.

In this study, we identify offshoring at the firm level by using firm-level data on imports by destination country at the product level. Combining this information with Major Industrial Groupings (MIGs), we aggregate product-level imports to firm-country imports of material inputs into the production process. Our data cover all firms and their trade with all countries; thus, our measure is likely to be more precise than most other measures used in the literature. $^{3}$

\footnotetext{
${ }^{3}$ In this paper, we resduce the potential problem of identifying intra-firm cross-border offshoring from international offshoring by introducing a dummy variable that separates multinational firms (which are capable
} 


\section{Theoretical links between institutional quality and offshoring}

One reason for observing a link between institutional quality and trade is that international exchange does not occur anonymously (Nunn, 2007). Before trade occurs, agents must agree on a contract. Because perfectly designed contracts are often not feasible, agents are left with imperfect contracts, and subsequent contract costs can be substantial. Institutions can reduce contract costs through several mechanisms: they can reduce the risk of opportunistic behavior, enhance law enforcement, secure property rights, reduce corruption, and clarify labor market regulations. ${ }^{4}$ Institutions can also influence the costs of monitoring and control. As noted by North (1991), good institutions may reduce the risk of defection by the other party and allow for more complex and efficient ways of organizing production and trade. Considering that contract costs can often determine whether a cross-border relationship is established, institutions are of critical importance and can be considered a source of comparative advantage.

One influential theoretical framework that is used to analyze firms' decisions to offshore in relation to institutions derives from the Grossman-Hart-Moore (GHM) property rights models (Hart and Moore, 1990; Grossman, Sanford and Hart, 1986; Hart, 1995). An important implication of these models is that not all activities should occur within a single firm. In the spirit of GHM, Antràs (2003) proposes a property rights model of outsourcing that shows that outsourcing capital-intensive inputs is relatively difficult. Antràs and Helpman (2004) builds a heterogeneous firm model that shows that firms must choose not only between producing in-house and producing outside the firm (outsourcing) but also between producing at home and producing abroad. Finally, Grossman and Helpman (2003, 2005) show that a good contracting environment increases firms’ propensity to offshore.

Institutional quality may also have composition effects. One implication of findings of Grossman and Helpman (2002), Antras (2003), and Feenstra and Hanson (2005) is that sensitive tasks are not easily outsourced. This difficulty arises because the contract required to ensure that property rights and firm-specific knowledge will not leak out is complex, time consuming, and costly to formulate.

of internal cross-border offshoring) from local firms. See Hijzen (2005) for an overview of different measures of offshoring and Michel and Rycx (2014) for a discussion on material and business service offshoring.

${ }^{4}$ See North (1991) and Massini et al. (2010). 
While most theoretical models explain North-South offshoring, they provide few insights into North-North offshoring. Considering that the bulk of worldwide offshoring involves North-North trade, Grossman and Rossi-Hansberg (2012) develop a framework for trade in tasks between similar countries. Their main proposition is that tasks that are easily codified and that demand limited interaction between headquarters and main production facilities will be offshored to countries with the lowest factor costs, whereas advanced tasks will be offshored to high-wage countries. ${ }^{5}$

As mentioned above, learning effects must also be considered. When a firm begins offshoring from a foreign market, the characteristics of the market's institutions and the firm's contractual partner are not fully known. After market entry, however, the firm will become more familiar with the contractual partner and the institutions of the target economy. If such learning occurs, entry barriers are reduced, and the firm's subsequent return to the target economy can be expected to be less sensitive to institutional quality in the source country (Aeberhardt et al., 2011; Fafchamps et al., 2002).

In sum, theoretical models suggest that (i) better contracting institutions favor offshoring, (ii) the sensitivity of offshoring to weak institutions varies across different types of firms, and (iii) learning effects influence the sensitivity of firms to the institutional quality of foreign markets with which they have previous experience. To empirically address issues involving different types of trade, the gravity model of trade has proven to be a good point of departure. We therefore continue with a discussion of that model.

\section{Empirical Approach}

We base our empirical analysis on the gravity model, which can explain trade remarkably well (Tinbergen, 1962). The gravity model is now well recognized to be consistent with several of the most common trade theories (Bergstrand, 1989 and Deardorff, 1998).

Anderson and van Wincoop (2003) show that the traditional specification of the gravity model suffers from omitted variables bias by neglecting the effects of relative prices on trade patterns and argue that inclusion of importer and exporter fixed effects yields consistent parameter estimates. However, the use of fixed effects also entails a cost, as fixed

\footnotetext{
${ }^{5}$ See Hakkala et al. (2014) for evidence on FDI and job tasks using similar Swedish micro data.
} 
effects eliminate all time-invariant information from the data. A common way to handle fixed effects is therefore to include various region-specific dummy variables. Other methods include using a two-step approach to model trade resistance as a function of observable variables (Anderson and van Wincoop, 2003 and Feenstra, 2004). Following Anderson and van Wincoop (2003), we estimate one-sided gravity models with country fixed effects included in all our estimations. ${ }^{6}$

One alternative approach is to also include firm fixed effects. This is however problematic due to the lack of time-series variation in aggregated data. Therefore, the debate in the gravity model literature centers on country fixed effects and period-specific fixed effects. To address the issue of firm fixed effects, we also estimate firm fixed-effects and dynamic panel-data models. Both of these models difference out all firm-country pair fixed effects. In addition to the firm fixed-effect estimation, the dynamic models allow us to look at the transitional dynamics in micro-level trade patterns.

Another concern is that the selection of firms into exports is nonrandom (Melitz, 2003). The unit of observation in our study is firm-country pairs; therefore, the data will contain many observations with zero trade. Thus, if selection into offshoring is nonrandom, failure to adjust for selection may lead to biased results. To account for zeros and selection, we apply the Heckman selection model and compare the results with corresponding OLS estimations. ${ }^{7}$ For the exclusion restriction in the Heckman models, we use data on skill intensity and export intensity at the firm level. ${ }^{8}$ Testing for the exclusion restriction indicates that these variables are valid.

\footnotetext{
${ }^{6}$ Fixed-effects in gravity models are discussed in e.g. Bendedicits and Salvatici (2007) and Bendedictis and Vicarelli (2009). Our reading of this literature points at two key issues: (i) Country fixed effects are important, not least because of relative prices changes. We therefore include country fixed effects in all our estimations, and (ii) Period-specific effects are important to capture period-specific shocks. We also include period-specific effects in all our estimations.

${ }^{7}$ As a robustness test, we have also estimated zero-inflated negative binomial models (results available upon request).

${ }^{8}$ Bernard and Jensen (2004) is an example in which skill intensity is used to explain selection with respect to internationalization. The motivation underlying the use of this measure is that highly productive and skillintensive firms are more internationalized than other firms. Similarly, exporters have overcome the internationalization barrier and are therefore more likely to engage in international offshoring.
} 


\subsection{Econometric modeling of institutional indices and factor analysis}

Our analysis includes 17 measures of institutional quality. To add structure to the analysis, we divide the institutional variables into three subgroups: (i) Politics, (ii) IPR and Rule of law, and (iii) Economic and trade freedom. In addition to these subgroups, we construct a Total index that combines all the institutional variables. Based on this grouping, we create two types of indices that are used to measure institutional quality. First, we normalize all institutional variables to range between 0 and 10, where higher numbers indicate "better" institutions. Then, for each group, we calculate the unweighted mean by measuring the annual average scores received by each country. As a result, all measures of institutional quality receive the same weight. Descriptive statistics are presented in Table A1 in the Appendix.

Additionally, as a refinement to the unweighted mean values, we apply factor analysis to create institutional indices. ${ }^{9}$ Factor analysis allows us to keep track of the degree to which each factor affects the total variation and the contribution of each underlying variable. To determine how many factors to use, we apply the Kaiser criterion, which stipulates that only factors with eigenvalues equal to or greater than one should be assessed. In our case, we thus use one factor loading for all indices.

Next, we evaluate the relative importance of the different institutional variables for each factor. Information on relative importance in terms of factor loadings is displayed in Table 1. The table shows that for the Politics factor, the variables Civil liberties and Political rights are most important. For IPR and Rule of law, we observe that all variables related to IPR and Rule of law have approximately the same loadings. Regarding the Economic and trade freedom factor, the institutional variable Freedom to trade internationally is most important, whereas loadings stemming from Fiscal freedom are almost irrelevant. Finally, Table 1 also shows that the factors absorb most of the variation of the underlying variables, with no proportion lower than 0.89 for different groupings of institutions.

-Table 1 about here-

\footnotetext{
${ }^{9}$ For an introduction to factor analysis, see Kim (1979).
} 


\subsection{Relationship-specific interactions}

As noted above, well-functioning institutions can be considered a source of comparative advantage. Nunn (2007) builds on Raush (1999) in constructing a relationship-specificity (RS) index that is used to examine, for different types of goods, the role of common personal interactions between a buyer and a seller in contract completion. Nunn shows that countries with well-developed institutions have a comparative advantage in goods that are intensive in buyer-seller interactions.

Several papers have examined how relationship-specific interactions affect various decisions of firms. ${ }^{10}$ Given the close connection among offshoring, relationshipspecific interactions, and contractual completion, failure to control for relationship-specific interactions may lead to misleading results. We therefore follow Nunn (2007) and others and interact measures of a country's institutional quality with the industry-specific RS index.

\subsection{Other variables and model specification}

Following Anderson and Wincoop (2003), we include population in our model, as rich countries tend to spend greater shares of their income on tradables and as, for a given GDP, a larger population implies lower per capita income. We also include an ownership variable that indicates whether a firm is a multinational enterprise (MNE). To account for firm-level gravity, we apply firm sales. Firm-level productivity is measured by using the Törnquist index (TFP). Finally, we include information on tariffs defined at the most disaggregated (product) level. Based on the above discussion, we estimate the following model:

$\ln (\text { Offshoring })_{i j c t}=\beta_{0}$ Inst $_{c t}+\beta_{1} z_{j}$ Inst $_{c t}+\beta_{2} X_{i j t}+\beta_{3} Z_{j c t}+\beta_{4} C_{c t}+\theta_{j}+\lambda_{c}+\delta_{t}+\varepsilon_{i j c t}$

where Offshoring ${ }_{i j c t}$ refers to imports of offshored material inputs by firm $i$ in industry $j$ from country $c$ at time $t$. Inst $t_{c t}$ is our measure of institutional quality (measured in several different

\footnotetext{
${ }^{10}$ Examples include Altomonte and Békés (2010) on trade and productivity; Casaburi and Gattai (2009) on intangible assets; Ferguson and Formai (2013) on trade, firm choice, and contractual institutions; Bartel, Lach, and Sicherman (2005) on outsourcing and relationship-specific interactions; Söderlund and Tingvall (2014) on export dynamics; and Kukenova and Strieborny (2009) on finance and relationship-specific investments.
} 
ways), $z_{j}$ is Nunn's (2007) time-invariant industry-specific measure of contract intensity (i.e., relationship-specific investments), $X$ is a vector of observable time-varying firm characteristics (Size, TFP, and MNE status), $Z$ is a vector of time-varying industry sourcecountry characteristics (trade-weighted tariffs), and $C$ is a vector of time-varying source country observables (GDP and Population). ${ }^{11}$ Finally, $\theta_{j}, \lambda_{c}$, and $\delta_{t}$ are industry, country, and year fixed effects, respectively, and $\varepsilon_{i j c t}$ is an error term. To allow for within-country correlation over time, standard errors are clustered at the country level.

Our focus is on the interaction between institutional quality and contract intensity $\left(z_{j} I n s t_{c t}\right)$, as in Nunn (2007) and subsequent papers. We thus analyze heterogeneous institutional-offshoring effects in sectors with differing degrees of RS intensity. A positive estimated coefficient for the interaction term $z_{j}$ Inst $t_{c t}$ implies that countries with strong institutions attract offshoring of contract-intensive inputs. The direct effect of industry contract intensity, $z_{j}$, is absorbed by industry fixed effects, $\theta_{j}$. We also present regressions with only the direct effect of institutional quality, i.e., without the interaction term $z_{j} I n s t_{c t}$.

\section{Data and Descriptive Statistics}

\section{Firm-level data}

Firm-level data are taken from several register-based data sets in Statistics Sweden that cover the entire private sector. First, the financial statistics contain detailed firm-level information on all Swedish firms in the private sector. Examples of these variables are value added, capital stock (book value), number of employees, total wages, ownership status, profits, sales, and industry affiliation.

Second, the Regional Labor Market Statistics (RAMS) includes data on all firms. The RAMS also adds firm information on the composition of the labor force with respect to educational level and demographics. ${ }^{12}$

Finally, firm-level data on offshoring are taken from Swedish Foreign Trade Statistics, collected by Statistics Sweden. These data identify imports at the product level and

\footnotetext{
${ }^{11}$ The variables included in $X, Z$, and $C$ are based on the estimated gravity equations in studies that use similar data (see Section 3.3). Note that geographical distance is absorbed by the country fixed effects.

${ }^{12}$ Plant-level data are aggregated at the firm level.
} 
country of origin from 1997 to 2005. Firm-level trade data cover all firms and all trade transactions with all non-EU countries. Data on trade with other EU countries, at the product level, are available for all firms with yearly imports above approximately 1.5 million SEK. According to figures from Statistics Sweden, the data incorporate 92 percent of the total trade within the EU. Material imports are defined at the five-digit level, according to NACE Rev 1.1, and grouped into MIG codes. ${ }^{13}$ The MIG codes classify imports according to their intended uses. In our analysis, we use the MIG definition of intermediate and consumption inputs to aggregate and define our offshoring variable.

Examining the data, we find that Swedish offshoring is concentrated in neighboring countries. Specifically, the top-five countries in terms of source country are Germany, the UK, France, Norway, and Finland, which account for 55 percent of total Swedish offshoring. Tingvall (2012), using similar data, finds that Europe accounts for 84 percent of total Swedish offshoring and that Asia accounts for a mere 10 percent, suggesting that Swedish offshoring is dominated by sourcing from other advanced suppliers that are located in close proximity to Sweden. In terms of specific industries, we find that the steel and chemical industry accounts for 38 percent of total offshoring, whereas the food and clothing industry accounts for only one percent of total offshoring. Finally, we find that that during the 1997-2005 period, the volume of material offshoring has increased by 37 percent but has remained in pair with GDP.

\section{Data on country characteristics}

GDP and population data are collected from the World Bank database. GDP data are in constant 2000 USD prices. Data on distance are based on CEPII's distance measure, which is a weighted measure that takes into account internal distances and population dispersion. ${ }^{14}$ Tariff data are obtained from the UNCTAD/TRAINS database. Detailed information on these variables is presented in the Appendix.

\footnotetext{
${ }^{13}$ MIGs are a European Community classification of products (NACE rev.1 aggregates).

${ }^{14}$ More information on CEPII's distance measure is provided in Mayer and Zignago (2006).
} 


\section{Institutional data}

Measuring institutional characteristics and addressing problems associated with capturing the quality of institutions are challenging. There are reasons to believe that several institutional variables are measured with error, which can influence the results. Moreover, many institutional variables are correlated with each other, and thus estimating regressions that include many different institutions is difficult. Finally, coverage across countries and over time differs widely among institutional variables; thus, results may be sensitive to the choice of variables.

Our strategy to address these problems is twofold. First, we use data on a large number of institutional variables and from many different data sources, covering different aspects of institutions. By using a large number of variables and data source, we avoid being dependent on just one or a few different measures and can account for potential heterogeneity in institutional quality. Second, we construct broader indices of institutional quality, which are described below.

Because some variables have limited coverage across countries and over time, not all of the available institutional variables can be used in the analysis. Further, our timeframe is constrained to the 1997-2005 period. Given these considerations, we end up with 17 different institutional variables in our main analysis. As mentioned above, we divide institutions into three main groups: Politics, IPR and Rule of law, and Economic and trade freedom. The choice of specific institutional variables is ultimately based on relevance and availability across time and country.

For Politics, we include political variables that capture regulations, political stability, political freedom, and governance quality, which are important factors for firms when making decisions regarding contracts with foreign suppliers. Details on these variables are presented in Table A2 in the Appendix. ${ }^{15}$

For IPR/Rule of law, we aim to capture various legal and property rights issues. These issues are related to legal structure, judicial independence, intellectual and property rights protection, and rule of law, all of which are associated with firms' willingness to sign

\footnotetext{
${ }^{15}$ Table A3 presents correlation coefficients between all our institutional variables.
} 
contracts with foreign suppliers. Among several alternatives but based on the restrictions above, we have chosen three variables, which are described in more detail in Table A2.

Finally, our variables related to Economic and trade freedom are based on institutional variables that affect firms' ability to engage in offshoring activities. In what way are regulations on trade and business activities related to international outsourcing? Again, we include a number of different measures, ranging from trade, financial, and investment freedom to variables capturing credit, labor, and business regulation and access to sound money.

Our institutional data are drawn from several different sources, including the World Bank database, Freedom House, the Polity IV database, the Fraser Institute, and the Heritage Foundation ${ }^{16}$.

The data from the Fraser Institute consist of variables associated with economic and business freedom. ${ }^{17}$

Freedom House provided us with data on institutional characteristics covering a wide range of indicators of political freedom, which include broad categories of political rights and civil liberties.

Data from the Polity IV database consist of variables that measure concepts such as institutionalized democracy and autocracy, polity fragmentation, participation regulation, and executive constraints.

Variables related to economic freedom are provided by the Heritage Foundation. The Heritage Foundation measures economic freedom according to ten core components, which are averaged to obtain an overall economic freedom score for each country.

Finally, we consider the Worldwide Governance Indicators (WGI) developed by Kaufman et al. (1999) and supplied by the World Bank. The WGI contain information on six measures of institutional quality: corruption, political stability, voice and accountability, government effectiveness, rule of law, and regulatory quality.

\footnotetext{
${ }^{16}$ The description of the variables originates from Teorell, Charron, Samanni, Holmberg, and Rothstein (2009), The Quality of Government Dataset, version 17 June 2009. See also the website of the Quality of Government Institute (www.qog.pol.gu.se/).

${ }^{17}$ The variables from the Fraser Institute that are included in our analysis are Legal structure and Security of property rights, Freedom to trade internationally, and Access to sound money.
} 
To ensure that the data are consistent across the time period, we restrict our analysis to firms in the manufacturing sector with at least 50 employees. All firm-level data sets are matched by unique identification codes.

\section{Results}

\subsection{Which institutions matter?}

Before we present our main specifications, we refer to Table A4 in the Appendix, which presents results regarding the effects of a large number of institutional variables. ${ }^{18}$ To obtain an overview of the individual impact of each institutional variable, we in Table A4 present the results of separate regressions involving each institutional variable independently. The institutional variables are divided into three main groups: Politics, IPR and Rule of Law, and Economic and trade freedom. To conserve space, Table A4 only includes results for the interaction term between institutional quality and contract intensity. This interaction term, which is analogous to the main variable of interest in Nunn (2007) and subsequent papers, indicates the association between institutional quality and offshoring, differentiated by Nunn's (2007) industry-specific RS index. A positive estimated coefficient for the interaction term indicates that an increase in institutional quality in a source country has a positive effect on the offshoring of RS-intensive inputs in particular.

In Table A4, the results presented in each column are the results of separate OLS regressions. All estimations include country, industry, and year fixed effects. Starting with the Politics*RS interaction variables in columns 1-6, we observe that the political variables are positively and significantly related to the level of firm offshoring. Despite differences in how the institutions are measured, the estimated coefficients are remarkably similar. The results indicate that a one-point increase in the political indices is associated with an increase in offshoring in the range of 10 to 16 percent. Comparing the different Politics variables, we observe that Regulatory quality and Political stability have the highest point estimates. The strong interaction between contract intensity and Regulatory quality is worth noting. Regulatory quality captures measures of market-unfriendly policies and excessive

\footnotetext{
${ }^{18}$ We have also estimated regressions on additional measures of institutional quality. The results for these variables are qualitatively similar and are available upon request.
} 
regulations on foreign trade and business development. These factors can be expected to significantly affect decisions regarding contracts with foreign suppliers.

Similar results apply to our estimations on the interaction between contract intensity $\left(z_{j}\right)$ and institutions, as captured by IPR and Rule of law. The three different variables in this group are all positively and significantly related to the amount of firm offshoring.

Our final group of institutional characteristics captures the different aspects of economic and business freedom. Positive and significant interaction effects are found for all the business freedom variables, with the exception of Fiscal freedom. The highest point estimates are obtained for the variables related to the regulation of credit, labor and business, and financial freedom. ${ }^{19}$

What are the quantitative effects of the results presented in Table A4? Consider the estimated coefficient for Rule of law. An estimated coefficient of 0.15 suggests that a oneunit increase in contract intensity is associated with a 16.2 percent $(16.2=1$-exp(0.15)) relative increase in offshoring. ${ }^{20}$ To understand the magnitude of this effect, Rule of law has a sample mean of 5.73 and a standard deviation of 1.71 (see Table A1); thus, a one-standard-deviation change in Rule of law is associated with a 1.3 percent $\left(1.3 \%=1\right.$-exp $\left.\left(1.71^{*} 0.15\right)\right)$ higher level of offshoring. The quantitative effects for the other institutional variables are of similar magnitude.

Table A4 also presents coefficient estimates for the control variables. The coefficients for the standard gravity variables, namely, firm size and GDP, have the expected signs and are statistically significant. One exception is the coefficient for TFP, which has a negative sign.

To analyze the impact on offshoring of total institutional quality and the relative importance of Politics, IPR and Rule of law, and Economic and trade freedom, Tables 2 and 3 present the results of our analysis of the summary indices of the institutional variables presented in Table A4. The use of summary indices allows us to determine which group of institutional variables is most important in firms' decisions to outsource production. It also

\footnotetext{
${ }^{19}$ Based on the discussion in Section 3 regarding the number of zero offshoring observations, we also estimated zero-inflated negative binomial (ZINB) models. The results with the ZINB models are robust.

${ }^{20}$ The nonlinearity imposed by the interaction term is illustrated and discussed below.
} 
makes us less dependent on individual institutional variables in terms of both what they measure and whether measurement errors arise. In Table 2, we present the results of two indices of overall institutional quality: (i) the unweighted average score of our 17 different institutional variables and (ii) a total index derived from factor analysis. In Table 3, we break down the total indices into three subindices, which capture politics, rule of law, and business freedom.

- Table 2 about here -

Starting with the unweighted index, columns (1) and (5) in Table 2 display results regarding the direct effects of institutions without accounting for differences in contract intensity. The results suggest a positive relationship between institutional quality and the level of offshoring. By adding the interaction term in columns (2) and (6), we observe that offshoring is more dependent on institutional quality in RS-intensive sectors than in sectors in which seller-buyer interactions are less frequent. From column 2, the marginal effect of

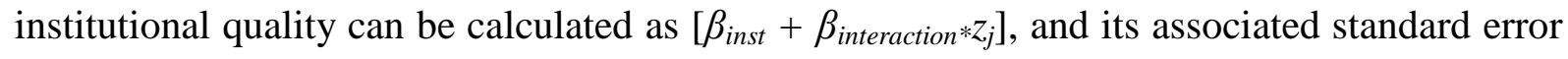
can be calculated as $\left[\sqrt{V\left(\beta_{\text {inst }}\right)}+z_{j}^{2} V\left(\beta_{\text {interaction }}\right)+2 z_{j} \operatorname{Cov}\left(\beta_{\text {inst }} \beta_{\text {interaction }}\right)\right]$. The estimated marginal effect and its confidence band from model 2 in Table 2 are displayed in Figure 1 over the full span of the RS index. As shown in Figure 1, the marginal impact of institutional quality is always positive, significant, and growing with the RS intensity of the industry.

- Figure 1 about here -

Table 2 also presents results for an analysis in which institutional quality is captured by factor analysis. Again, when country fixed effects are included, both models show that an increase in institutional quality has a relatively large effect on offshoring in RS-intensive sectors, 
although the direct effect of institutions is less clear. ${ }^{21}$ To further analyze the robustness of the results in Table 2, in Table A5, we repeat the estimations in Table 2 with the covariates lagged by one period. Using lagged covariates allows for an analysis of transition dynamics and may reduce potential endogeneity problems. The institutional quality of the source countries can be reasonably assumed to be exogenously given by the individual firm. The use of lagged covariates leads to slightly reduced parameter estimates but does not alter the significance of the results.

To control for transitional dynamics in offshoring and firm fixed effects, we estimate dynamic panel data models (see the last two columns in Table A5). ${ }^{22}$ The system GMM estimator differences out all cross-sectional variation between firms and countries. More precisely, estimating a firm-country fixed-effect model or a dynamic panel data model implies that we control for approximately $2200 * 113=248,600$ fixed effects (2200 firms and 113 countries) for each year.

We find that applying the system GMM estimator leads to an overall decrease in the significance of the results. Specifically, using firm-country fixed effects the institutional variables becomes insignificant, suggesting the importance of cross-sectional differences. ${ }^{23}$ This is a well known issue in the estimation of the Gravity model of trade. The efficiency vs. bias trade-off using a large set of dummy variables is discussed in some detail in Bendedicits and Salvatici (2007) and Bendedictis and Vicarelli (2009). The discussion in these papers points at the importance of country fixed effects for picking up unobserved price changes, suggesting an analysis based on country fixed effects (Bendedictis and Vicarelli, 2009; Bendedicits and Salvatici, 2007; Baldwin and Taglioni, 2006).

In Table 3, we proceed and divide institutional quality into the three subgroups: Politics, IPR and Rule of law, and Economic and trade freedom. For all three subindices of institutional quality, we observe a positive and significant relationship between the level of

\footnotetext{
${ }^{21}$ Note that the estimate of the direct effect depends on the value of the RS index and that the direct effect is evaluated at an RS index of zero, a value outside the observed span of the RS index.

${ }^{22}$ The system GMM estimator uses first differenced and level versions of the estimating equation, where lagged values and lagged differences can serve as valid instruments (Arellano and Bover, 1995; Blundell and Bond, 1998). The differentiated instruments are assumed to be uncorrelated with the unobserved fixed effects, implying that first differentiated variables can act as instruments for variables in levels.

${ }^{23}$ Test for serial correlation suggests inclusion of lags 1-3 of the dependent variable. Testing over identifying restrictions suggests that the applied IV-matrix is valid. See Table A5 for information on these tests. To reduce the size of the IV-matrix and to avoid over-identification of the IV matrix, the system GMM models are estimated using principal component transformed and collapsed IV matrices.
} 
offshoring and the interaction between institutional quality and contract intensity. Some variation exists in the quantitative effects, but the qualitative message is clear: improved institutional quality increases offshoring in RS-intensive industries. ${ }^{24}$

- Table 3 about here -

How do the results with respect to Politics, IPR and Rule of law, and Economic and trade freedom compare with one another? The results for the different indices of institutional quality are relatively similar. The largest interaction effect is found for the index of business characteristics and RS. ${ }^{25}$ This result suggests that a country's business climate is especially important for contract completion in contract-intensive industries.

Different measures of institutional quality are well known to be correlated with each other. This is also illustrated in the correlation matrix in Table A3. Accordingly, including different measures in the same regression and evaluating the individual contribution of different components become problematic. ${ }^{26}$

In summary, the results in Table 3 confirm the findings of our earlier regressions, namely, that well-functioning institutions are especially important for offshoring in contract-intensive industries and that the largest impact is associated with institutional characteristics that reflect the business climate. However, once again, the exact quantitative effects appear to vary somewhat across specifications and institutional areas.

\footnotetext{
${ }^{24}$ As with Table 2, we have also estimated regressions with only the direct effect of institutional quality, i.e., not the interaction of institutional quality with contract intensity. The results show a positive and statistically significant estimated coefficient for institutional quality in all cases except for the index variables that capture IPR/Law. The results are available upon request.

${ }^{25}$ F-tests of whether the direct effect and the interaction effect are equal to zero are rejected at the 5 or 1 percent levels in all cases except for the specifications with IPR/Law.

${ }^{26}$ To analyze how the simultaneous use of our three different measures of institutional quality affect the results, we also run regressions with all institutional variables and their interaction terms in the same model. Using all institutional variables in the same model leads to an overall reduced significance in the different institutional indices, driven by the high correlation between the different measures of institutional quality. The results are available upon request.
} 


\subsection{Offshoring and $R \& D$}

We now use firm-level data on R\&D expenditures to further examine which types of firms and inputs are most affected by the institutional characteristics of countries from which offshoring is conducted.

R\&D and innovative activities involve sensitive information, and outsourcing often involves the transfer of management control, decision making, and firm-specific knowledge to an external supplier-particularly with offshoring of advanced production. Although such arrangements can reduce costs, firms risk suffering from technology leakage (Adams, 2005). Hence, for R\&D-intensive firms and firms that offshore R\&D-intensive production, contract completion is crucial. We therefore hypothesize that high-technology firms and firms that produce R\&D-intensive goods are more reluctant than other firms to offshore activities to countries with weak institutions and limited intellectual property right protection. We analyze this in Table 4, where we present results related to how institutional quality in target economies varies with respect to the R\&D intensity of offshoring firms and the R\&D content of offshored material inputs.

- Table 4 about here -

To examine the link among offshoring, institutions, and R\&D, we first classify firms into two groups according to their R\&D intensity. In columns 1-3, firms are classified according to the R\&D intensity of their home industry (above or below the median), whereas in column 4 , firms are categorized according to the R\&D intensity of their offshored material inputs. As the latter analysis only involves regressions based on observations with positive offshoring flows, in these estimations, we have no observations with zero trade and no selection into offshoring to account for. When analyzing the impact of institutions on the offshoring of goods that differ in R\&D-intensity, we therefore use OLS.

Table 4 presents separate regressions for high and low R\&D firms with the use of different institutional indices. Regarding our results for high and low R\&D firms, the results are clear. Regardless of the econometric specification and the type of institution, we observe that offshoring by firms in R\&D-intensive industries is more sensitive to weak 
institutions than that by firms in other industries. Although some variation exists with respect to the quantitative effects, the qualitative message is clear: offshoring is especially sensitive to the institutional quality of the source country if the firm is in an industry (e.g., transport equipment) that is both RS and R\&D intensive. ${ }^{27}$ These results indicate that the sensitivity of firm production to R\&D influences the effect of institutional quality on a firm's choice of outsourcing location. Table 4 also shows that the quantitative effects of institutional quality for high R\&D firms are of similar magnitude to those in Tables 2 and 3, which include the estimated effects for all firms.

Next, we analyze how the R\&D intensity of inputs is related to institutional characteristics. The results are presented in column 4. Analogously to the analysis above, low and high $R \& D$ levels now refer to the $R \& D$ intensity of the offshored material inputs. When firms are differentiated with respect to the R\&D intensity of their offshored inputs, the results are similar, although smaller in magnitude, to those obtained when firms are differentiated with respect to industry R\&D intensity. A highly significant and positive effect of institutional quality is found for firms with higher than median R\&D content in their offshored inputs. For low R\&D offshoring firms, a smaller point estimate of the relationship between institutions and offshoring is obtained.

When institutions are divided into our three main groups, we find that the results for the R\&D intensity of the inputs are driven by institutions related to Economic and trade freedom. For this group of institutions, the relationship between institutional quality and level of offshoring is much stronger for the high $R \& D$ group than for the low $R \& D$ group. This result suggests that institutions that govern business freedom and trade regulations are of particular importance in the offshoring of $R \& D$-intensive inputs.

In sum, the results shown in Table 4 indicate that the intensity of R\&D activities and the sensitivity of both production and offshoring content to institutions are related to the importance of institutions with respect to offshoring activities.

\footnotetext{
${ }^{27}$ We also estimated models in which the institutional variables are interacted with R\&D expenditures. The qualitative results are unchanged.
} 


\subsection{Offshoring survival and learning}

Institutional quality not only affects offshoring in a static manner but also has implications for trade flow dynamics and learning. To address these issues, we first present some descriptive statistics. Table 5 presents statistics on the average volume of offshoring by duration and institutional quality.

-Table 5 about here-

The average volume of offshore inputs is nearly four times larger in trade with countries with strong institutions than in trade with countries with weak institutions. However, Table 5 shows no overwhelming evidence of differences in volume between countries with strong and weak institutions for a given duration of an offshoring spell. Instead, differences in average volume are driven by the distribution of spell durations. Large volumes are associated with long-lasting trade flows, which are more common in trade with countries with strong institutions than in trade with countries with weak institutions.

The relationship between institutional quality and the duration of offshoring spells can be further investigated by estimating regression equations based on the duration of observed offshoring spells. To conserve space, we only present the results for Heckman models. Table 6 presents the results of regressions separated by spell length.

-Table 6 about here-

In the selection equation, the interaction term suggests that the sensitivity of weak institutions increases with contract length and that the impact is magnified by the RS intensity of the sector. That is, firms that are sensitive to weak institutions, particularly those in RS-intensive sectors, are also best able to maintain long-term relationships. The results for the volume equation show a similar pattern. The interaction term for spells that last for 4-7 years is 3 to 4 higher than that for one-year spells. This result indicates that differences in 
institutional sensitivity between inputs with different levels of RS are more pronounced in long-lasting trade relationships than in short-term relationships.

In Table 7, we continue the analysis by examining firms that return to a market with which they have previous experience. Both the learning to trade and the learning by trade models indicate that learning about a market is costly, and when knowledge is acquired, such knowledge does not necessarily vanish (Fafchamps, 2002; Miaojie and Mi, 2011). Examples of market-specific knowledge range from knowledge about rules and regulations to knowledge about preferences and personal contacts with business partners and government officials. Thus, the costs of returning to a (familiar) market are expected to be lower when such knowledge is acquired. We examine this hypothesis by analyzing firms that return to a market from which they have previously sourced inputs. Specifically, we examine whether sensitivity to weak institutions decreases with the number of spells of previous market experience. $^{28}$

-Table 7 about here-

The results presented in Table 7 suggest that previous market experience is important but that this effect is limited to one spell of previous market experience. With no previous market experience, both the direct effect of institutions and the interaction effect between RS and institutions are positive and significant. After the initial spell of previous market experience, however, we observe no further differences in the impact of institutions across inputs characterized by differing degrees of RS. That is, after the first spell, the interaction term becomes insignificant, whereas the estimated direct impact of institutions remains significant, but drops from 4.7 to 4.3 . For the $3^{\text {rd }}$ and $4^{\text {th }}$ spell, the direct impact of institutional quality is further reduced.

These findings are consistent with the notion that learning through active engagement in a market is strongest in contract-intensive sectors. That is, the sectors in which institutions are most important for contract completion are also those in which we observe the largest degree of institutional learning.

\footnotetext{
${ }^{28}$ Table A6 presents a list of the countries included in the trade data.
} 


\section{Summary and Conclusions}

Previous research on institutions has found that weak institutions can distort markets, hamper investment, and alter patterns of trade and investment. However, little is known about the impact of institutional quality in target economies on offshoring. Given the importance of offshoring in firms' internationalization strategies, this lack of knowledge is unfortunate. As offshoring is an activity in which firm-specific and sensitive information must occasionally be shared with external agents in other jurisdictions, institutional barriers may strongly affect offshoring.

Using detailed Swedish firm-level data combined with country characteristics, we analyze how various institutional characteristics of target economies affect offshoring by Swedish firms. Our results, based on a large set of institutional measures, indicate that a positive relationship exists between institutional quality and firm-level offshoring. Institutional strength therefore strongly influences both the choice of destination country and the volume of offshored material inputs.

We also present evidence of the differing effects of institutional quality on firms, depending on the sector and type of firm. Specifically, R\&D-intensive firms depend on innovation and technology development, and such R\&D activities can be conducted in-house or outsourced. Although outsourcing arrangements may reduce costs, outsourcing firms may risk technology leakage. We therefore analyze whether R\&D-intensive firms and firms that offshore R\&D-intensive goods are more sensitive to weak institutions than other firms. The results are clear. Regardless of the econometric specification that is used and the type of institution that is analyzed, a strong relationship is observed between institutional quality and offshoring by firms in high R\&D-intensity industries. In contrast, this relationship is much weaker for firms in low R\&D-intensity industries. We also show that the contract intensity of offshored inputs is important in this relationship.

In analyzing offshoring spells of different durations and repeated offshorers, we find that firms that are relatively sensitive to weak institutions dominate long-term relationships. In addition, regarding institutional learning, we find that offshorers that have offshored previously in a given market become less dependent on institutional quality when 
they return to the same source market and that this learning effect is strongest in contractintensive sectors. Hence, weak institutions in source countries can deter offshoring in numerous ways.

\section{References}

Abram, C.E. (2008), “How Much Do Perceptions of Corruption Really Tell Us?”, Economics, 2(3).

Adams, J.D., (2005), "Industrial R\&D Laboratories: Windows on Black Boxes?", The Journal of Technology Transfer, 30: 129-137.

Aeberhardt, R., Ines, B. and Fadinger, H. (2011), "Learning, Incomplete Contracts and Export Dynamics: Theory and Evidence from French Firms,” Working Paper 1006, Department of Economics, University of Vienna.

Altomonte, C. and Békés, G., (2010), "Trade Complexity and Productivity," CeFiG Working Papers 12, Center for Firms in the Global Economy.

Alvarez, R. and Lopez, R. (2008), "Is Exporting a source of productivity spillovers?” Review of World Economics 144(4): 723-749.

Anderson, J.E. (1979), “A Theoretical Foundation for the Gravity Equation”, American Economic Review, 69(1): 106-116.

Anderson J.E., and Marcoullier, D. (2002), "Insecurity and the Pattern of Trade: An Empirical Investigation,” The Review of Economics and Statistics, 84(2): 342-352.

Anderson, J.E. and van Wincoop, E. (2003), "Gravity with gravitas: A solution to the border puzzle”, American Economic Review, 93(1): 170-192.

Antràs, P. (2003), "Firms, Contracts, and Trade Structure”, Quarterly Journal of Economics,118(4): 1375-1418.

Antràs, P. and Helpman, E. (2004), “Global Sourcing”, Journal of Political Economy, 112(3): 552-580.

Antràs, P. and Helpman, E. (2006), “Contractual Frictions and Global Sourcing”. NBER WP No. 12747.

Arellano, M. and O. Bover (1995), “Another Look at the Instrumental Variable Estimation of Error-Components Models”, Journal of Econometrics, Vol. 68: 29-51.

Araujo, L., Mion, G. and Ornelas, E. (2012), "Institutions and Export Dynamics," Mimeo. Michigan State University and London School of Economics.

Baldwin, R. and Taglioni D. (2006), Gravity for Dummies and Dummies for Gravity Equations," NBER WP: No. 12516.

Bartel, A., Lach, S and Sicherman, N. (2005), “Outsourcing and Technological Change”, NBER WP No. 11158.

Benedicits, De Luca, and Vicarelli, C. (2009), Dummies for Gravity and Gravity for Policies: Mission Impossible?, Mimeo. www.ReserchGate.net.

Benedicits, De Luca, and Salvatici, L. (2007), The Trade Impact of European Union Preferential Policies: An Analysis Through Gravity Models. (Eds. Benedicits, De Luca, and Salvatici, L). Springer, London, New York. 
Bergstrand, J.H. (1985), “The Gravity equation in International trade: some microeconomic foundations and empirical evidence”: Review of Economics and Statistics, 67(3): 474481.

Bergstrand, J.H. (1989), “The Generalized Gravity Equation, Monopolistic Competition, and the Factor-Proportions Theory in International Trade", Review of Economics and Statistics, 71(1): 143-53.

Bernard, A. and Jensen, J.B. (2004), "Why some firms export", Review of Economics and Statistics, 86(2): 561-569.

Blundell, R., and S. Bond (1998), "Initial Conditions and Moment Restrictions in Dynamic Panel Data Models", Journal of Econometrics, Vol. 87: 115-43.

Caetano, J.M. and Caleiro, A. (2005), “Corruption and Foreign Direct Investment, What kind of relationship is there?”, Working Paper No. 18, University of Évora, Department of Economics.

Casaburi, L. and Gattai, V. (2009), "Why FDI? An Empirical Assessment Based on Contractual Incompleteness and Dissipation of Intangible Assets", Working Paper No. 164, University of Milano-Bicocca, Department of Economics.

Dai, M. and Yu, M., (2012), "R\&D, Absorptive Capacity and Learning by Exporting: FirmLevel Evidence from China”, The World Economy.

Deardorff, A.V., (1998), "Determinants of Bilateral Trade: Does Gravity Work in a Neoclassical World?" in Jeffrey A. Frankel (ed.), The regionalization of the world economy, Chicago: University of Chicago Press (1998): 7-22.

Depken C.A., and Sonora R.J. (2005), "Asymmetric Effects of Economic Freedom on International Trade Flows”, International Journal of Business and Economics, 4(2): 141-155.

Egger, P.H. and Winner, H. (2006), "How Corruption Influences Foreign Direct Investment: A Panel Data Study”, Economic Development and Cultural Change, 54(2): 459-86.

Fafchamps, M., Hamine, S.E. and Zeufack, M. (2002), "Learning to Export”, World Bank Policy Research Paper, No. 2827.

Feenstra, R.C., Hanson, G.H. (1996), "Globalization, outsourcing, and wage inequality”, American Economic Review 86 (2): 240-245.

Feenstra, R. C. and Hanson. G. H. (2005), “Ownership and Control in Outsourcing to China: Estimating the Property Rights Theory of the Firm", Quarterly Journal of Economics,120(2): 729-762.

Ferguson, S. and Formai, S. (2013), "Institution-Driven Comparative Advantage, Complex Goods and Organizational Choice", Journal of Institutional Economics, 90: 193-200.

Grossman, G.M., Sanford. J. and Hart, O. D. (1986), "The Costs and Benefits of Ownership: A Theory of Vertical and Lateral Integration”, Journal of Political Economy, 94(4): 691-719.

Grossman, G.M. and Helpman, E. (2002), "Integration versus Outsourcing in Industry Equilibrium”, Quarterly Journal of Economics, 117(1): 85-120.

Grossman, G.M. and Helpman, E. (2003), "Outsourcing versus FDI in Industry Equilibrium”, Journal of the European Economic Association, 1(2-3): 317-327.

Grossman, G.M., and Helpman, E. (2005), “Outsourcing in a Global Economy”, Review of Economic Studies, 72: 135-159.

Grossman, G.M. and Rossi-Hansberg, E. (2012), “Tasks Trade Between Similar Countries”, Econometrica, 80(2), 593-629.

Hart, O.D. (1995), "Firms, Contracts and Financial Structure,” Oxford Clarendon Press.

Hart, O.D. and Moore, J. (1990), "Property Rights and the Nature of the Firm," Journal of Political Economy, 98(6): 1119-58. 
Habib, M. and Zurawicki, L. (2002), “Corruption and Foreign Direct Investment,” Journal of International Business Studies, 33(2): 291-307.

Hakkala, K., Norbäck P-J. and Svaleryd, H. (2008), ”Asymmetric Effects of Corruption on FDI: Evidence from Swedish Multinational Firms," The Review of Economics and Statisitics, 90(4): 627-642.

Hakkala, K., Heyman F. and Sjöholm F. (2014), "Multinational Firms, Acquisitions and Job Tasks”, European Economic Review 66: 248-265.

Hijzen, A. (2005), "A Bird's Eye View of International Outsourcing: Data, Measurement and Labour Demand Effects," Economie Internationale, CEPII research center, issue 104: 45-63.

Hummels, D., Rapoport, D., Yi, K. (1998). "Vertical specialization and the changing nature of world trade,” Federal Reserve Bank of New York Economic Policy Review 4 (2): 79-99.

Hummels, D., Ishii, J. and Yi, K. (2001), "The nature and growth of vertical specialisation in world trade”, Journal of International Economics 54 (1): 75-96.

Kaufman, D., Kraay, A. and Zoido, P. (1999), “Aggregating Governance Indicators”, World Bank Policy Research Working Paper No. 2195.

Kim, J-O. (1979), “Introduction to Factor Analysis: What It Is and How To Do It”, Sage Publications, Inc., Thousands Oaks, USA.

Kukenova, M. and Strieborny, M., (2009), "Investment in Relationship-Specific Assets: Does Finance Matter?," MPRA Paper 15229, University Library of Munich, Germany.

Mayer, T. and Zignago, S. (2006), “Notes on CEPII's distance measures”, www.cepii.fr.

Márquez-Ramos, L., Mart’tinez-Zarzoso, I. and Suárez-Burgute, C. (2010), “Trade Policy Versus Institutional Trade Barriers: An Application using "Good Old” OLS”, The Open-Access, Open-Assessment E-Journal.http://hdl.handle.net/1902.1/16723.

Massini, S., Pern-Ajchariyawong, N. and Lewin A.Y. (2010), "Role of corporate-wide offshoring strategy on offshoring drivers, risks and performance”, Industry and Innovation, 17(4): 337-371.

Mayer, T. and Zignago, S. (2006), "Notes on CEPII's distance measures", MPRA Paper 26469.

Melitz, M. (2003), “The impact of trade on intra-industry reallocations and aggregate industry productivity”, Econometrica, 71( 6): 1695-1725.

Méon, P-G., and Sekkat, K. (2006), "Institutional quality and trade: which institutions? Which trade?”, DULBEA Working Papers 06-06.RS, ULB, Universite Libre de Bruxelles.

Miaojie, Y. and Mi, D. (2011), "Pre-Export R\&D, Exporting and Productivity Gains: Evidence from Chinese Firms”, CTRG WP. No. 2011/011.

Michel, B. and Rycx, F. (2014), "Productivity Gains and Spillover from Offshoring”, Review of International Economics, 22(1): 73-85.

Mocan, N. (2007). "What Determines Corruption? International Evidence form Microdata", Economic Inquiry, 46(4): 493-510.

Niccolini, M. (2007), “Institutions and Offshoring Decision”, CESifo WP. No. 2074.

North D.C. (1991), “Institutions”, The Journal of Economic Perspectives, 5(1): 97-112.

Nunn, N. (2007), "Relationship-Specificity, Incomplete Contracts and the Pattern of Trade”, Quarterly Journal of Economics, 122(2): 569-600.

Ranjan, P., and Lee, J.Y. (2007), "Contract Enforcement and International Trade", Economics and Politics, 19(2): 191-218.

Rauch, J.E. and Watson, J. (2003), "Starting Small in an Unfamiliar Environment", International Journal of Industrial Organization, 21(7): 1021-1042.

Segerstrom, P.S. and Stepanok, S. (2013), "Learning How To Export”, Kiel Institute for the World Economy, WP. No 1801. 
Söderlund, B. and Tingvall Gustavsson, P. (2014). "Dynamic Effects of Institutions on FirmLevel Exports”. Review of World Economics, DOI: 10.1007/s10290-013-0181-2.

Teorell, Charron, Samanni, Holmberg and B. Rothstein (2009), The Quality of Government Dataset, version 17 June 2009-

Tinbergen, J. (1962), "Shaping the World Economy: Suggestions for an International Economic Policy”, New York: The Twentieth Century Fund.

Tingvall, Gustavsson, P. (2012), "Dynamic Effects of Corruption on Offshoring”, Ratio Working Paper No. 182.

Turrini, A., and Ypersele, T.V. (2010), "Traders, Courts, and the Border Effect Puzzle", Regional Science and Urban Economics 40: 81-91.

Table 1. Factor Determinants: Rotated Factor Loadings (orthogonal rotation). Top factors in bold style, bottom factors in cursive.

Factor determinant:

\section{Politics:}

Government efficiency (WB)

0.72

0.72

Regulatory quality (WB)

0.88

$\mathbf{0 . 8 8}$

Civil liberties (FH)

0.91

Political rights (FH)

0.92

0.43

Institutionalized democracy (IV)

0.92

0.33

0.87

0.25

IPR/Law:

Legal structure, property rights (FI)

Property rights (HF)

0.94

0.89

Rule of Law (WB)

0.92

0.85

0.95

0.90

\section{Economic and trade freedom:}

Freedom to trade internationally ( FI)

Reg. of credit, labor, and business( FI)

Access to sound money (FI)

Business freedom (HF)

Financial freedom (HF)

Fiscal freedom (HF)

Investment freedom (HF)

Freedom to trade (HF)

$\begin{array}{ll}\mathbf{0 . 8 4} & 0.72 \\ 0.79 & 0.76 \\ 0.77 & 0.64 \\ 0.64 & 0.67 \\ 0.79 & 0.58 \\ & \\ 0.04 & -0.14 \\ 0.74 & 0.52 \\ 0.60 & 0.48\end{array}$

\section{Proportion}

0.89

1.04

0.99

0.80

Notes: Institutional data are collected from several different sources: the World Bank database (WB), the Freedom House (FH), the Polity IV database (IV), the Fraser Institute (FI), and the Heritage Foundation (HF). See Section 4 for more details on the data. Proportion measures the proportion of variance accounted for by the factor. 
Figure 1. Marginal effect of institutional quality on offshoring

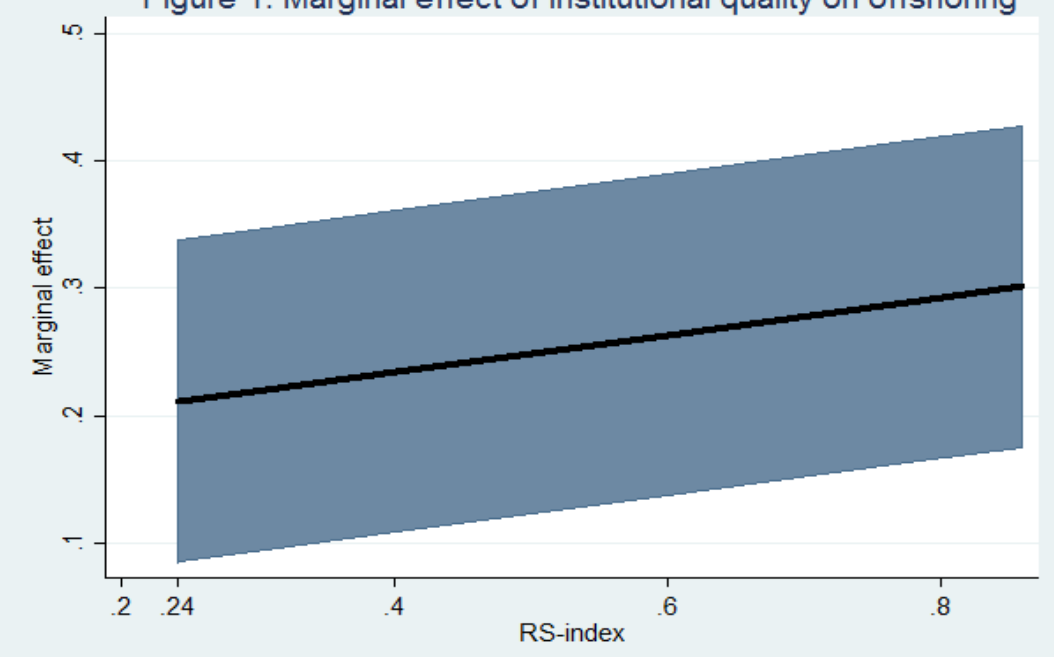

Note: Marginal effect estimates from Table 2, column 2. 
Table 2. Offshoring and Institutions, 1997-2005. Unweighted and factor-based institutional indices. Indices based on all institutional variables. OLS

Heckman target

\begin{tabular}{|c|c|c|c|c|c|c|c|c|}
\hline $\begin{array}{l}\text { Unweighted index: Inst } t_{c t} \\
\text { Unweighted index interaction: } \\
z_{j} I_{n s t} c_{c t}\end{array}$ & $\begin{array}{c}(1) \\
0.254 \\
(0.125)^{* *}\end{array}$ & $\begin{array}{c}(2) \\
0.176 \\
(0.120) \\
0.145 \\
(0.049)^{* * *}\end{array}$ & (3) & (4) & $\begin{array}{c}(5) \\
0.270 \\
(0.155)^{*}\end{array}$ & $\begin{array}{c}(6) \\
0.101 \\
(0.148) \\
0.489 \\
(0.105)^{* * *}\end{array}$ & (7) & (8) \\
\hline Factor index: Inst $t_{c t}$ & & & $\begin{array}{c}0.036 \\
(0.130)\end{array}$ & $\begin{array}{c}-0.414 \\
(0.176)^{* *} \\
0.835 \\
(0.267)^{* * *}\end{array}$ & & & $\begin{array}{c}0.520 \\
(0.191)^{* * *}\end{array}$ & $\begin{array}{c}-0.146 \\
(0.240)^{*} \\
1.235 \\
(0.400)^{* * *}\end{array}$ \\
\hline Factor index interaction: $z_{j} I n s t_{c t}$ & & & & & & & & \\
\hline Full set of control variables & yes & yes & yes & yes & yes & yes & yes & yes \\
\hline $\begin{array}{l}\text { Country dummies } \\
\text { Adj. } R^{2}\end{array}$ & $\begin{array}{l}\text { yes } \\
0.25\end{array}$ & $\begin{array}{l}\text { yes } \\
0.25\end{array}$ & $\begin{array}{l}\text { yes } \\
0.25\end{array}$ & $\begin{array}{c}\text { yes } \\
0.25\end{array}$ & yes & yes & yes & yes \\
\hline Observations & 122,836 & 122,836 & 122,836 & 122,836 & 122,836 & $1,579,751$ & $1,579,751$ & $1,579,751$ \\
\hline
\end{tabular}

Notes: The dependent variable is log offshoring in the OLS estimations and offshoring in levels in the Heckman estimations. Robust standard errors are presented within parenthesis, clustered by country. ${ }^{*},{ }^{* *}$, and ${ }^{* * *}$ indicate significance at the 10,5 , and 1 percent levels, respectively. All estimations include country, industry ( 2 -digit), and year fixed effects. Additional exclusion restriction variables in the Heckman estimations are Share of skilled labor and Firm export ratio. Additional control variables not shown are distance, log GDP, population, tariffs, log TFP, MNE dummy, and log firm size. ${ }^{\text {(a) }}$ Absorbed fixed effects. 
Table 3. Offshoring and Institutions, 1997-2005. Unweighted and factor-based institutional indices.

Country fixed-effect model (OLS)

Heckman target

Index based on factor analysis:

Politics: Inst $c_{c t}$

(2)

(3)

(4)

(5)

0.135

(0.293)

Politics interaction: $z_{j} I n s t_{c t}$

$(0.261)^{* * *}$

IPR/Law: Inst $_{c t}$

IPR/Law: Inst ${ }_{c t}$

IPR/Law interaction: $z_{j}$ Inst $_{c \text { }}$

Ec. and trade freedom: Inst $_{c t}$

Ec. and trade freedom interaction:

$z_{i} I_{n s t} c_{c t}$

$-0.572$

$(0.210)^{* * *}$

$-0.572$

$(0.210)^{* *}$

0.744

$(0.254)^{* * *}$

$-0.440$

$(0.167)^{* * *}$

1.114

$(0.314)^{* * *}$
(8) (9)

(11)

(12)

0.429

(0.359)

1.179

$(0.405)^{* * * *}$

$-0.316$

(0.292)

$-0.316$

$(0.292)$

1.043

$(0.370)^{* * * *}$

$-0.265$

$(0.220)$

1.235

$(0.415)^{* * *}$

Unweighted indices:

Politics: Inst ${ }_{c}$

Politics interaction: Inst $_{c t}$

Inst $_{c t}$

0.140

Economic and trade freedom: Inst ${ }_{c t}$

Ec. and trade freedom interaction: $z_{i}$ Inst $_{c}$

Notes: The dependent variable is log offshoring in the OLS estimations and offshoring in levels in the Heckman estimations. Robust standard errors are presented within parenthesis, clustered by country. ${ }^{* * *}$, and ${ }^{*}$ indicate significance at the 10,5, and 1 percent levels, respectively. All estimations include country, industry (2-digit), and year fixed effects. Additional exclusion restriction variables in the Heckman estimations are Share of skilled labor and Firm export ratio. Additional control variables not shown are distance, log GDP, population, tariffs, log TFP, MNE dummy, and log firm size. 
Table 4. Offshoring and Institutions. Impact of differences in firms’ R\&D intensity and in the R\&D intensity of firms’ imports.

\section{OLS Heckman Heckman OLS}

target selection

Firms' $R \& D$ intensity

LOW R\&D FIRMS

All institutions:

Unweighted index: Inst ${ }_{c t}$

$\begin{array}{cccc}0.298 & 0.255 & -0.073 & 0.152 \\ (0.132)^{* *} & (0.148)^{*} & (0.058) & (0.125) \\ -0.048 & 0.103 & 0.191 & 0.054 \\ (0.050) & (0.054)^{*} & (0.016)^{* * *} & (0.040) \\ 0.209 & 0.084 & -0.150 & -0.288 \\ (0.153) & (0.178) & (0.063)^{* *} & (0.169)^{*} \\ -0.192 & 0.124 & 0.326 & 0.454 \\ (0.239) & (0.270) & (0.097)^{* * *} & (0.260)^{*}\end{array}$

By inst. category (factor-based index):

Politics: Inst $t_{c t}$

$\begin{array}{cccc}0.439 & 0.363 & -0.119 & 0.234 \\ (0.255)^{*} & (0.279) & (0.091) & (0.248) \\ -0.201 & 0.219 & 0.437 & 0.479 \\ (0.208) & (0.251) & (0.135)^{* * *} & (0.237)^{* *} \\ 0.069 & 0.005 & -0.082 & -0.433 \\ (0.184) & (0.217) & (0.079) & (0.189)^{* *} \\ -0.217 & 0.077 & 0.275 & 0.435 \\ (0.220) & (0.243) & (0.107) & (0.239)^{*} \\ 0.261 & 0.123 & -0.170 & -0.170 \\ (0.142)^{*} & (0.150) & (0.065)^{* *} & (0.144) \\ -0.163 & 0.171 & 0.362 & 0.548 \\ (0.268) & (0.307) & (0.127)^{* *} & (0.286)^{*}\end{array}$

$z_{j}$ Inst $t_{c t}$

\section{HIGH R\&D FIRMS}

All institutions:

Unweighted index: Inst $t_{c t}$

$\begin{array}{cccc}0.074 & -0.101 & -0.087 & 0.222 \\ (0.133) & (0.178) & (0.041)^{* *} & (0.151) \\ 0.207 & 0.566 & 0.105 & 0.171 \\ (0.077)^{* * *} & (0.125)^{* * *} & (0.026)^{* * *} & (0.062)^{* * *} \\ -0.442 & -0.502 & -0.049 & -0.270 \\ (0.237)^{*} & (0.330) & (0.085) & (0.237) \\ 0.613 & 0.830 & -0.040 & 0.686 \\ (0.350)^{*} & (0.483)^{*} & (0.122) & (0.322)^{* *}\end{array}$

By inst. category (factor indices)

Politics: Inst $t_{c t}$

0.366

0.793

0.069

0.288

$(0.364)$

(0.466)*

$(0.083)$

$(0.455)$

0.587

0.761

$-0.126$

0.667

(0.362)

$(0.500)$

$(0.110)$

$(0.307)^{* *}$

IPR/Law: Inst ${ }_{c t}$

$-0.478$

$-0.138$

0.065

$-0.365$

$(0.267$

$(0.375)$

(0.078)

$(0.266)$

IPR/Law interaction: $z_{j} I n s t_{c t}$

0.385

0.628

$-0.135$

0.503

$(0.336)$

$(0.444)$

$(0.114)$

$(0.296)^{*}$

Ec. and trade freedom: Inst ${ }_{c t}$

$-0.544$

$-0.461$

$-0.013$

$-0.459$

$(0.258)$

(0.344)

$(0.074)$

$(0.237)^{*}$

1.103

1.271

$-0.028$

1.167

$z_{j}$ Inst $t_{c t}$

$(0.434)^{* *} \quad(0.565)^{* *}$

(0.121)

$(0.431)^{* * *}$

Notes: The dependent variable is log offshoring in the OLS estimations and offshoring in levels in the Heckman estimations. Robust standard errors are presented within parenthesis, clustered by country. ${ }^{* * *}$, and $^{* * *}$ indicate significance at the 10,5 , and 1 percent levels, respectively. All estimations include country, industry (2-digit), and year fixed effects. Additional exclusion restriction variables in the Heckman estimations are Share of skilled labor and Firm export ratio. Additional control variables not shown are distance, log GDP, population, tariffs, log TFP, MNE dummy, and log firm size. Low (High) R\&D refers to firms in industries with R\&D intensity below (above) the median in columns 1-3. In column 4, Low (High) R\&D refers to firms in industries with R\&D intensity in offshoring below (above) the median. 
Table 5. Average Volume of Offshoring: By spell duration and institutional quality.

\begin{tabular}{llll}
\hline Spell duration & High institutional quality & $\begin{array}{l}\text { Medium institutional } \\
\text { quality }\end{array}$ & $\begin{array}{l}\text { Low institutional } \\
\text { quality }\end{array}$ \\
\hline Average volume & 450 & 139 & 124 \\
$1 \mathrm{y}$ & 19 & 12 & 13 \\
$2-4 \mathrm{y}$ & 76 & 65 & 70 \\
$5-7 \mathrm{y}$ & 220 & 168 & 406 \\
$8 \mathrm{y}^{+}$ & 8,96 & 744 & 1,172 \\
Continuous offshorers & 2,139 & 2,172 & 4,431
\end{tabular}

Notes: 1y, 2-4y, and 5-7y represent offshoring flows that are started and cancelled. $8 y+$ refers to offshoring activities that have occurred for at least eight years and that are ongoing in the last year of observation. Volumes in 1,000 SEK.

Table 6. Offshoring and Institutions: By duration of offshoring spells, 1997-2005.

\begin{tabular}{|c|c|c|c|}
\hline & 1 year & 2-3 years & 4-7 years \\
\hline All institutions: & \multicolumn{3}{|c|}{ Heckman volume equation } \\
\hline Unweighted index: Inst ${ }_{c t}$ & $\begin{array}{l}-0.123 \\
(0.149)\end{array}$ & $\begin{array}{c}0.055 \\
(0.426)\end{array}$ & $\begin{array}{l}-0.203 \\
(0.330)\end{array}$ \\
\hline $\begin{array}{l}\text { Unweighted index interaction: } \\
z_{j} I n s t_{c t}\end{array}$ & $\begin{array}{c}0.147 \\
(0.068)^{* *}\end{array}$ & $\begin{array}{c}0.485 \\
(0.083)^{* * *}\end{array}$ & $\begin{array}{c}0.643 \\
(0.243) * * *\end{array}$ \\
\hline Factor index: $z_{j} I n s t_{c t}$ & $\begin{array}{l}-0.213 \\
(0.176)\end{array}$ & $\begin{array}{l}-0.538 \\
(0.400)\end{array}$ & $\begin{array}{l}-0.208 \\
(0.486)\end{array}$ \\
\hline \multirow[t]{2}{*}{ Factor index interaction: $z_{j} I n s t_{c t}$} & $\begin{array}{c}0.550 \\
(0.220)^{* * *}\end{array}$ & $\begin{array}{c}1.494 \\
(0.346)^{* * *}\end{array}$ & $\begin{array}{c}1.605 \\
(0.823)^{*}\end{array}$ \\
\hline & \multicolumn{3}{|c|}{ Selection equation } \\
\hline Unweighted index: Inst $t_{c t}$ & $\begin{array}{l}-0.056 \\
(0.043)\end{array}$ & $\begin{array}{l}-0.055 \\
(0.080)\end{array}$ & $\begin{array}{l}-0.022 \\
(0.051)\end{array}$ \\
\hline $\begin{array}{l}\text { Unweighted index interaction: } \\
z_{j} I n s t_{c t}\end{array}$ & $\begin{array}{c}0.070 \\
(0.011)^{* * *}\end{array}$ & $\begin{array}{c}0.133 \\
(0.015)^{* * *}\end{array}$ & $\begin{array}{c}0.136 \\
(0.022)^{* * *}\end{array}$ \\
\hline Factor index: $I n s t_{c t}$ & $\begin{array}{c}0.028 \\
(0.043)\end{array}$ & $\begin{array}{l}-0.059 \\
(0.088)\end{array}$ & $\begin{array}{c}-0.148 \\
(0.079)^{*}\end{array}$ \\
\hline Factor index interaction: $z_{j} I n s t_{c t}$ & $\begin{array}{c}0.070 \\
(0.051)\end{array}$ & $\begin{array}{c}0.187 \\
(0.079)^{* *}\end{array}$ & $\begin{array}{c}0.318 \\
(0.104)^{* * *}\end{array}$ \\
\hline \multicolumn{4}{|c|}{$\begin{array}{l}\text { Notes: Robust standard errors are presented within parenthesis, clustered by country. *, }{ }^{* *} \text {, and }{ }^{* * *} \text { indicate } \\
\text { significance at the } 10,5 \text {, and } 1 \text { percent levels, respectively. All estimations include country, industry (2-digit), } \\
\text { and year fixed effects. Additional exclusion restriction variables in the Heckman estimations are Share of skilled } \\
\text { labor and Firm export ratio. Additional control variables not shown are distance, log GDP, population, tariffs, } \\
\text { log TFP, MNE dummy, and log firm size. Wald test of indep. eqns. p-value }=0.000 \text {. p-value, Inverse Mills Ratio } \\
=0.000\end{array}$} \\
\hline
\end{tabular}


Table 7. Offshoring and Institutions. Analysis of repeated offshorers.

SPELL 1. $\quad$ SPELL $2 . \quad$ SPELL $3 . \quad$ SPELL 4.

\begin{tabular}{|c|c|c|c|c|}
\hline \multirow[t]{2}{*}{ All institutions: } & \multicolumn{4}{|c|}{$\begin{array}{c}\text { Estimation } 1 . \\
\text { Institutional quality index based on factor analysis }\end{array}$} \\
\hline & \multicolumn{4}{|c|}{ LOGIT SELECTION EQUATION } \\
\hline Factor index: Inst $t_{c t}$ & $\begin{array}{l}4.7027 \\
(0.847)^{* * *}\end{array}$ & $\begin{array}{l}4.3373 \\
(0.8238)^{* * *}\end{array}$ & $\begin{array}{l}4.0302 \\
(0.959)^{* * *}\end{array}$ & $\begin{array}{l}3.8380 \\
(1.467)^{* * *}\end{array}$ \\
\hline Factor index interaction: $z_{j} I n s t_{c t}$ & $\begin{array}{l}2.0323 \\
(0.651)^{* * *}\end{array}$ & $\begin{array}{l}0.8744 \\
(0.669)\end{array}$ & $\begin{array}{l}0.8227 \\
(0.9528)\end{array}$ & $\begin{array}{l}1.6360 \\
(2.242)\end{array}$ \\
\hline Full set of controls & yes & yes & yes & yes \\
\hline Observations & \multicolumn{4}{|c|}{$1,506,098$} \\
\hline
\end{tabular}

\footnotetext{
Notes: Robust standard errors are presented within parenthesis, clustered by country. ${ }^{*},{ }^{* *}$, and ${ }^{* * *}$ indicate significance at the 10, 5, and 1 percent levels, respectively. All estimations include country, industry (2-digit), and year fixed effects. Additional control variables not shown are distance, log GDP, population, tariffs, log TFP, MNE dummy, share of skilled labor, firm export ratio, and log firm size.
} 


\section{Appendix}

Table A1. Descriptive Statistics, 1997-2005.

\begin{tabular}{|c|c|c|c|c|c|c|c|c|c|c|c|}
\hline Variable & Mean & Stdv total & Stdv be/w & Variable & Mean & Stdv total & Stdv be/w & Variable & Mean & Stdv total & Stdv be/w \\
\hline \multicolumn{4}{|c|}{ Core variables } & \multicolumn{4}{|c|}{ Institutional index: Political } & \multicolumn{4}{|c|}{ Institutional index: Economic and trade freedoms } \\
\hline $\ln$ (Distance) & 8.39 & 0.91 & -- & Pol. Stab. & 5.49 & 1.59 & 4.67 & Trade freedom & 7.26 & 0.87 & 2.64 \\
\hline $\ln (\mathrm{GDP})$ & 24.4 & 1.98 & 22.8 & Gov. Eff. & 5.94 & 1.71 & 8.69 & Freedom of the world & 6.77 & 0.81 & 3.19 \\
\hline $\ln$ (Population) & 16.5 & 1.50 & 40.5 & Reg. qual. & 6.00 & 1.52 & 6.19 & Financial regulation & 6.28 & 0.71 & 2.19 \\
\hline Tariffs & 0.005 & 0.02 & 2.13 & Civil Lib. & 6.87 & 2.32 & 3.98 & Sound money & 7.95 & 1.38 & 1.95 \\
\hline ln(Firm offshoring) & 5.64 & 3.03 & 2.28 & Democracy & 7.46 & 2.46 & 4.87 & Business freedom & 5.25 & 1.59 & 1.83 \\
\hline MNE status & 0.57 & 0.49 & 1.66 & Political Rights & 7.19 & 2.85 & 4.27 & Ec. freedom index & 6.49 & 0.92 & 3.82 \\
\hline ln(Firm sales) & 12.3 & 1.24 & 4.63 & Inst. Democracy & 6.88 & 3.18 & 4.29 & Financial freedom & 5.92 & 1.72 & 2.33 \\
\hline $\ln ($ Firm TFP) & 3.41 & 1.78 & 1.90 & Polity score & 7.88 & 2.54 & 4.02 & Fiscal freedom & 8.17 & 0.89 & 2.77 \\
\hline Firm Skill intensity & 0.18 & 0.14 & 4.68 & Unweighted index & 6.71 & 2.02 & 5.77 & Investment freedom & 6.18 & 1.56 & 2.22 \\
\hline Firm Export ratio & 0.33 & 0.33 & 1.60 & Factor & 0.30 & 0.85 & 3.90 & Freedom to trade & 6.91 & 1.27 & 1.96 \\
\hline \multirow[t]{8}{*}{ Contract intensity $\left(z_{j}\right)$} & 0.55 & 0.18 & 5.36 & & & & & Unweighted index & 6.72 & 0.87 & 3.78 \\
\hline & & & & & & & & Factor & 0.09 & 0.87 & 2.00 \\
\hline & & & & \multicolumn{4}{|c|}{ Institutional index: IPR/Law } & \multicolumn{4}{|c|}{ Institutional index: All institutions } \\
\hline & & & & Legal structure & 6.04 & 1.65 & 3.32 & Unweighted index & 6.60 & 1.30 & 6.6 \\
\hline & & & & Property Rights & 5.87 & 2.03 & 3.64 & Factor & 0.04 & 0.97 & 4.57 \\
\hline & & & & Rule of law & 5.73 & 1.71 & 10.4 & & & & \\
\hline & & & & Unweighted index & 5.88 & 1.72 & 5.73 & & & & \\
\hline & & & & Factor & 0.01 & 0.93 & 6.2 & & & & \\
\hline
\end{tabular}

Notes: Descriptive statistics based on the total regression sample at the firm-country-year level. Stdv total refers to the total standard deviation. Stdv be/w is the between standard deviation

divided by the within standard deviation. Distance is based on the CEPII distance measure, which is a population-weighted measure that accounts for internal distances and population dispersion (source: Worldwide Governance Indicators (WGI)). GDP is in constant 2,000 US\$ (source: Penn). Population is the total population (source: Penn). Tariffs originate from six-digit HS tariff data and are aggregated up to the three-digit level of SNI (Swedish Industrial Classification) by using trade shares as weights (source: UNCTAD TRAINS database). 
Table A2. Description of Institutional Variables. See Section 4 for data sources. Descriptions of variables are based on Teorell, Charron, Samanni, Holmberg, and Rothstein (2009).

Variable Description

Politics

Political Stability

Government Effectiveness

Regulatory Quality

Civil Liberties

Political Rights

Institutionalized Democracy

IPR/Law

Legal Structure and Security of Property Rights

Property Rights

Rule of Law - Estimate

Economic and Trade Freedom

Freedom to Trade Internationally Index consisting of the following indicators: (i)Taxes on international trade, (ii)Regulatory trade barriers, (iii) Actual size of trade sector compared to expected size, (iv) Difference between official exchange rate and black market rate and (v) International capital market controls.

Economic Freedom of the World Index (current)

Regulation of Credit, Labor and Business

Access to Sound Money

Business Freedom

Financial Freedom

Fiscal Freedom

Investment Freedom

Trade Freedom

Combines several indicators which measure perceptions of the likelihood that the government in power will be destabilized.

Combines into a single grouping responses on the quality of public service provision, the quality of the bureaucracy, the competence of civil servants. The main focus of this index is on "inputs" required for the government to be able to produce and implement good policies.

Captures measures of market-unfriendly policies as well as excessive regulations in foreign trade and business development, factors that are of importance when taking decisions on contracts with foreign suppliers.

Measures civil liberties which allow for the freedoms of expression and belief, associational and organizational rights, rule of law, and personal autonomy without interference from the state.

Measures political rights which enable people to participate freely in the political process, including the right to vote freely for distinct alternatives in legitimate elections, compete for public office, join political parties and organizations, and elect representatives who have a decisive impact on public policies and are accountable to the electorate.

Includes three main interdependent elements: (i) the presence of institutions and procedures through which citizens can express effective preferences about alternative policies and leaders, (ii) the existence of institutionalized constraints on the exercise of power by the executive and (iii) the guarantee of civil liberties to all citizens in their daily lives and in acts of political participation.

Index consisting of the following indicators: (i) Judicial independence: The judiciary is independent and not subject to interference by the government or parties in dispute, (ii) Impartial courts: A trusted legal framework exists for private businesses to challenge the legality of government actions or regulations, (iii) Protection of intellectual property, (iv) Military interference in rule of law and the political process, and (v) Integrity of the legal system.

Measures the degree to which a country's laws protect private property rights and the degree to which its government enforces those laws. It also accounts for the possibility that private property will be expropriated. In addition, it analyzes the independence of the judiciary, the existence of corruption within the judiciary, and the ability of individuals and businesses to enforce contracts. The less certain the legal protection of property is and the greater the chances of government expropriation of property are, the higher a country's score is.

Includes several indicators which measure the extent to which agents have confidence in and abide by the rules of society. These include perceptions of the incidence of crime, the effectiveness and predictability of the judiciary, and the enforceability of contracts. Together, these indicators measure the success of a society in developing an environment in which fair and predictable rules form the basis for economic and social interactions and the extent to which property rights are protected.

ex 21 components designed to identify the consistency of institutional arrangements and policies with economic freedom in five major areas: (i) size of government, (ii) legal structure and security of property rights, (iii) access to sound money, (iv) freedom to trade internationally and $(\mathrm{v})$ regulation of credit, labor and business

Index consisting of the following indicators: (i) Credit Market Regulations, (ii) Labor Market Regulations and (iii) Business Regulations.

Index consisting of the following indicators: (i) Average annual growth of the money supply in the last five years minus average, (ii) annual growth of real GDP in the last ten years, (iii) Standard inflation variability in the last five years, (iv) Recent inflation rate and (v) Freedom to own foreign currency bank accounts domestically and abroad.

A score encompassing 10 components, all weighted equally, based on objective data from the World Bank's Doing Business study. These include components related to starting a business, obtaining a license and closing a business.

A factor measuring the relative openness of each country's banking and financial system by determining: the extent of government regulation of financial services; the extent of state intervention in banks and other financial services; the difficulty of opening and operating financial services firms (for both domestic and foreign individuals); and government influence on the allocation of credit.

Composed of three quantitative components in equal measure: (i) The top tax rate on individual income, (ii) The top tax rate on corporate income and (iii) Total tax revenue as a percentage of GDP.

Reflects each country's policies toward foreign investment, as well as its policies toward capital flows internally, in order to determine its overall investment climate.

Based on two inputs: (i) The trade-weighted average tariff rate and (ii) Non-tariff barriers. 
Table A3. Correlations between Institutional Variables, 1997-2005.

\begin{tabular}{|c|c|c|c|c|c|c|c|c|c|c|c|c|c|c|c|c|c|}
\hline & $\begin{array}{l}\text { Political } \\
\text { stability }\end{array}$ & $\begin{array}{l}\text { Govemment } \\
\text { eff. }\end{array}$ & Reg. quality & $\begin{array}{l}\text { Civil } \\
\text { liberties }\end{array}$ & $\begin{array}{l}\text { Political } \\
\text { rights }\end{array}$ & $\begin{array}{l}\text { Instit. } \\
\text { democracy }\end{array}$ & $\begin{array}{l}\text { Leg. str., } \\
\text { prop. rights }\end{array}$ & $\begin{array}{l}\text { Property } \\
\text { rights }\end{array}$ & Rule of law & $\begin{array}{l}\text { Freedom to } \\
\text { trade int. }\end{array}$ & $\begin{array}{l}\text { Reg. of cred. } \\
\& \text { bus. }\end{array}$ & $\begin{array}{l}\text { Acc. sound } \\
\text { money }\end{array}$ & $\begin{array}{l}\text { Business } \\
\text { freedom }\end{array}$ & $\begin{array}{l}\text { Financial } \\
\text { freedom }\end{array}$ & $\begin{array}{l}\begin{array}{l}\text { Fiscal } \\
\text { freedom }\end{array} \\
\end{array}$ & $\begin{array}{l}\text { Investm } \\
\text { freedom }\end{array}$ & $\begin{array}{l}\text { Trade } \\
\text { freedom }\end{array}$ \\
\hline Political stability & 1 & & & & & & & & & & & & & & & & \\
\hline Govemment eff. & 0.795 & 1 & & & & & & & & & & & & & & & \\
\hline Reg. quality & $0.779^{* * *}$ & $0.941^{* * *}$ & 1 & & & & & & & & & & & & & & \\
\hline Civil liberties & $0.624^{* * *}$ & $0.682^{* * * *}$ & $0.725^{* * *}$ & 1 & & & & & & & & & & & & & \\
\hline Political rights & $0.563^{* * *}$ & $0.614^{* * * *}$ & $0.667^{* * *}$ & $0.913^{* * *}$ & 1 & & & & & & & & & & & & \\
\hline Instit. democracy & $0.479 * * *$ & $0.562^{* * *}$ & $0.606^{* * *}$ & $0.848^{* * * *}$ & $0.919^{* * *}$ & 1 & & & & & & & & & & & \\
\hline Leg. str., prop. rights & $0.748 * * *$ & $0.882^{* * *}$ & $0.838^{* * * *}$ & $0.561^{* * *}$ & $0.495^{* * *}$ & $0.417^{* * * *}$ & 1 & & & & & & & & & & \\
\hline Property rights & $0.688^{* * *}$ & $0.846^{* * *}$ & $0.865^{* * *}$ & $0.625^{* * *}$ & $0.575^{* * *}$ & $0.504^{* * *}$ & $0.863^{* * *}$ & 1 & & & & & & & & & \\
\hline Rule of law & $0.826^{* * * *}$ & $0.958^{* * *}$ & $0.912^{* * *}$ & $0.650^{* * *}$ & $0.586^{* * *}$ & $0.516^{* * *}$ & $0.908^{* * *}$ & $0.871^{* * *}$ & 1 & & & & & & & & \\
\hline Freedom to trade int. & $0.639 * * *$ & $0.736^{* * *}$ & $0.809 * * *$ & $0.591^{* * *}$ & $0.561^{* * *}$ & $0.513^{* * *}$ & $0.690^{* * *}$ & $0.720^{* * *}$ & $0.711^{* * *}$ & 1 & & & & & & & \\
\hline Reg. of cred. \& bus. & $0.608^{* * *}$ & $0.720^{* * * *}$ & $0.758^{* * *}$ & $0.561^{* * *}$ & $0.476^{* * * *}$ & $0.383^{* * *}$ & $0.719^{* * *}$ & $0.714^{* * * *}$ & $0.702^{* * *}$ & $0.666 * * *$ & 1 & & & & & & \\
\hline Acc. sound money & $0.542 * * *$ & $0.621^{* * *}$ & $0.682^{* * *}$ & $0.521^{* * *}$ & $0.449 * * *$ & $0.394^{* * *}$ & $0.577^{* * *}$ & $0.567^{* * *}$ & $0.618^{* * * *}$ & $0.661^{* * *}$ & $0.622^{* * *}$ & 1 & & & & & \\
\hline Business freedom & $0.501 * * *$ & $0.653 * * *$ & $0.672^{* * *}$ & $0.482^{* * *}$ & $0.415^{* * *}$ & $0.359 * * *$ & $0.623^{* * *}$ & $0.652^{* * *}$ & $0.647^{* * *}$ & $0.493^{* * *}$ & $0.570^{* * *}$ & $0.380^{* * *}$ & 1 & & & & \\
\hline Financial freedom & $0.489 * * *$ & $0.572^{* * *}$ & $0.699 * * *$ & $0.609^{* * *}$ & $0.544^{* * *}$ & $0.508^{* * *}$ & $0.475^{* * * *}$ & $0.573^{* * *}$ & $0.521^{* * * *}$ & $0.605^{* * *}$ & $0.668^{* * *}$ & $0.604^{* * *}$ & $0.498^{* * *}$ & 1 & & & \\
\hline Fiscal freedom & $-0.222 * * *$ & $-0.307^{* * *}$ & $-0.214^{* * *}$ & $-0.183^{* * *}$ & $-0.143^{* * *}$ & $-0.143^{* * *}$ & $-0.349 * * *$ & $-0.235^{* * *}$ & $-0.317^{* * *}$ & $-0.107^{* * *}$ & $0.00836^{* * *}$ & $-0.0582^{* * *}$ & $-0.0420^{* * *}$ & $-0.0416^{* * *}$ & 1 & & \\
\hline Investm freedom & $0.413^{* * *}$ & $0.514^{* * * *}$ & $0.649 * * *$ & $0.537^{* * * *}$ & $0.524^{* * *}$ & $0.485^{* * *}$ & $0.473^{* * *}$ & $0.564^{* * * *}$ & $0.472^{* * *}$ & $0.653^{* * * *}$ & $0.471^{* * *}$ & $0.524^{* * * *}$ & $0.435^{* * *}$ & $0.628^{* * *}$ & $-0.0875^{* * *}$ & 1 & \\
\hline Trade freedom & $0.470^{* * *}$ & $0.553^{* * *}$ & $0.617 * * *$ & $0.493 * * *$ & $0.476^{* * * *}$ & $0.453^{* * *}$ & $0.441^{* * *}$ & $0.528 * * *$ & $0.517^{* * * *}$ & $0.678^{* * *}$ & $0.496 * * *$ & $0.450^{* * * *}$ & $0.447 * * *$ & $0.441 * * *$ & $0.0538^{* * * *}$ & $0.452 * * *$ & 1 \\
\hline
\end{tabular}


Table A4. Offshoring and Institutions, 1997-2005. Institutional variables included one-by-one. Interaction effects.

\begin{tabular}{|c|c|c|c|c|c|c|c|c|c|c|c|c|c|c|c|c|c|}
\hline \multirow{2}{*}{$\begin{array}{l}\text { Variables: } \\
\left.\text { 1. Political stability* } z_{j}\right)\end{array}$} & \multicolumn{6}{|c|}{ Politics } & \multicolumn{3}{|c|}{ IPR and Rule of law } & \multicolumn{8}{|c|}{ Economic and trade freedom } \\
\hline & $(0.055)$ & & & & & & & & & & & & & & & & \\
\hline 2. Government Eff. ${ }^{*}\left(z_{j}\right)$ & & $\begin{array}{c}0.137 * * * \\
(0.049)\end{array}$ & & & & & & & & & & & & & & & \\
\hline 3. Reg. quality* $\left(z_{j}\right)$ & & & $\begin{array}{c}0.150 * * * \\
(0.050)\end{array}$ & & & & & & & & & & & & & & \\
\hline 4. Civil Liberties* $\left(z_{j}\right)$ & & & & $\begin{array}{c}0.117 * * * \\
(0.043)\end{array}$ & & & & & & & & & & & & & \\
\hline 5. Political rights* $\left(z_{j}\right)$ & & & & & $\begin{array}{c}0.114 * * * \\
(0.037)\end{array}$ & & & & & & & & & & & & \\
\hline 6. Instit. democracy* $\left(z_{j}\right)$ & & & & & & $\begin{array}{c}0.102 * * * \\
(0.037)\end{array}$ & & & & & & & & & & & \\
\hline 7. Legal structure, property rights ${ }^{*}\left(z_{j}\right)$ & & & & & & & $\begin{array}{c}0.130 * * * \\
(0.045)\end{array}$ & & & & & & & & & & \\
\hline 8. Property rights $*\left(z_{j}\right)$ & & & & & & & & $\begin{array}{c}0.134 * * * \\
(0.047)\end{array}$ & & & & & & & & & \\
\hline 9. Rule of $\operatorname{Law}^{*}\left(z_{j}\right)$ & & & & & & & & & $\begin{array}{c}0.150 * * * \\
(0.051)\end{array}$ & & & & & & & & \\
\hline 10. Freedom to trade ${ }^{*}\left(z_{j}\right)$ & & & & & & & & & & $\begin{array}{l}0.108^{* *} \\
(0.045)\end{array}$ & & & & & & & \\
\hline 11. Reg. of credit and business ${ }^{*}\left(z_{j}\right)$ & & & & & & & & & & & $\begin{array}{c}0.163 * * * \\
(0.060)\end{array}$ & & & & & & \\
\hline 12. Access to sound money $\left(z_{j}\right)$ & & & & & & & & & & & & $\begin{array}{c}0.136 * * * \\
(0.041)\end{array}$ & & & & & \\
\hline 13. Business freedom* ${ }^{*}\left(z_{j}\right)$ & & & & & & & & & & & & & $\begin{array}{c}0.159 * * * \\
(0.054)\end{array}$ & & & & \\
\hline 14. Financial freedom ${ }^{*}\left(z_{j}\right)$ & & & & & & & & & & & & & & $\begin{array}{c}0.182 * * * \\
(0.069)\end{array}$ & & & \\
\hline 15. Fiscal freedom ${ }^{*}\left(z_{j}\right)$ & & & & & & & & & & & & & & & $\begin{array}{c}0.094 \\
(0.063)\end{array}$ & & \\
\hline 16. Investm. freedom* $\left.{ }^{*} z_{j}\right)$ & & & & & & & & & & & & & & & & $\begin{array}{l}0.117^{* *} \\
(0.053)\end{array}$ & \\
\hline 17. Freedom to trade $*\left(z_{j}\right)$ & & & & & & & & & & & & & & & & & $\begin{array}{l}0.114 * * \\
(0.047)\end{array}$ \\
\hline $\ln (\mathrm{GDP})$ & $\begin{array}{l}1.308^{* * * *} \\
(0.454)\end{array}$ & $\begin{array}{l}1.309 * * * \\
(0.438)\end{array}$ & $\begin{array}{l}1.249 * * * \\
(0.419)\end{array}$ & $\begin{array}{l}1.314 * * * \\
(0.374)\end{array}$ & $\begin{array}{l}1.312 * * * \\
(0.398)\end{array}$ & $\begin{array}{l}1.294 * * * \\
(0.401)\end{array}$ & $\begin{array}{l}1.332 * * * \\
(0.423)\end{array}$ & $\begin{array}{l}1.283^{* * * *} \\
(0.410)\end{array}$ & $\begin{array}{l}1.297 * * * \\
(0.451)\end{array}$ & $\begin{array}{l}1.209 * * * \\
(0.418)\end{array}$ & $\begin{array}{l}1.237 * * * \\
(0.404)\end{array}$ & $\begin{array}{l}1.072 * * * \\
(0.382)\end{array}$ & $\begin{array}{l}1.230 * * * \\
(0.415)\end{array}$ & $\begin{array}{l}1.187 * * * \\
(0.379)\end{array}$ & $\begin{array}{l}1.269 * * * \\
(0.408)\end{array}$ & $\begin{array}{l}1.305 * * * \\
(0.400)\end{array}$ & $\begin{array}{l}1.276 * * * \\
(0.413)\end{array}$ \\
\hline MNE & $\begin{array}{l}0.267 * * * \\
(0.042)\end{array}$ & $\begin{array}{l}0.267 * * * \\
(0.042)\end{array}$ & $\begin{array}{l}0.267^{* * * *} \\
(0.042)\end{array}$ & $\begin{array}{l}0.267 * * * \\
(0.042)\end{array}$ & $\begin{array}{l}0.267 * * * \\
(0.042)\end{array}$ & $\begin{array}{l}0.267 * * * * \\
(0.042)\end{array}$ & $\begin{array}{l}0.267 * * * \\
(0.042)\end{array}$ & $\begin{array}{l}0.267 * * * \\
(0.042)\end{array}$ & $\begin{array}{l}0.267 * * * \\
(0.042)\end{array}$ & $\begin{array}{l}0.267 * * * \\
(0.042)\end{array}$ & $\begin{array}{l}0.268^{* * *} \\
(0.042)\end{array}$ & $\begin{array}{l}0.267 * * * \\
(0.042)\end{array}$ & $\begin{array}{l}0.267 * * * \\
(0.042)\end{array}$ & $\begin{array}{l}0.268^{* * *} \\
(0.042)\end{array}$ & $\begin{array}{l}0.266^{* * * *} \\
(0.042)\end{array}$ & $\begin{array}{l}0.266 * * * * \\
(0.042)\end{array}$ & $\begin{array}{l}0.267 * * * \\
(0.042)\end{array}$ \\
\hline $\ln$ (population) & $\begin{array}{l}-3.806^{* *} \\
(1.550)\end{array}$ & $\begin{array}{l}-3.806 * * \\
(1.489)\end{array}$ & $\begin{array}{l}-3.5499^{* *} \\
(1.14)\end{array}$ & $\begin{array}{l}-3.475 * * \\
(1.41)\end{array}$ & $\begin{array}{l}-4.011 * * * \\
(1.441)\end{array}$ & $\begin{array}{l}-3.870 * * * \\
(1.439)\end{array}$ & $\begin{array}{l}-3.728 * * \\
(.164)\end{array}$ & $\begin{array}{l}-3.750^{* *} \\
(1.569)\end{array}$ & $\begin{array}{l}-3.835 * * \\
(1.732)\end{array}$ & $\begin{array}{l}-3.896^{* *} \\
(1.491)\end{array}$ & $\begin{array}{l}-3.8466^{* *} \\
(1.509)\end{array}$ & $\begin{array}{l}-3.557 * * \\
(1.411)\end{array}$ & $\begin{array}{l}-4.078 * * * \\
(1.510)\end{array}$ & $\begin{array}{l}-3.298 * * \\
(.159)\end{array}$ & $\begin{array}{l}-3.550 * * \\
(1.481)\end{array}$ & $\begin{array}{l}-3.750 * * \\
(1.530)\end{array}$ & $\begin{array}{l}-3.742 * * \\
(.191)\end{array}$ \\
\hline $\ln ($ firm size) & $0.491 * * *$ & $0.491 * * *$ & $0.491 * * *$ & $0.491 * * *$ & $0.491 * * *$ & $0.491 * * *$ & $0.492 * * *$ & $0.492 * * *$ & $0.491 * * *$ & $0.491 * * *$ & $0.491 * * *$ & $0.491 * * *$ & $0.491 * * *$ & $0.491 * * *$ & $0.492 * * *$ & $0.491 * * *$ & $0.491^{* * *}$ \\
\hline $\ln (\mathrm{TFP})$ & $\begin{array}{l}(0.041) \\
-0.049 * * *\end{array}$ & $\begin{array}{l}(0.041) \\
-0.049 * * *\end{array}$ & $\begin{array}{l}(0.041) \\
-0.049 * * *\end{array}$ & $\begin{array}{l}(-0.041) \\
-0.049 * * *\end{array}$ & $\begin{array}{l}(0.041) \\
-0.049 * * *\end{array}$ & $\begin{array}{l}(0.041) \\
-0.048^{* * *}\end{array}$ & $\begin{array}{l}(0.041) \\
-0.049^{* * *}\end{array}$ & $\begin{array}{l}(0.041) \\
-0.049 * * *\end{array}$ & $\begin{array}{l}(0.041) \\
-0.050^{* * * *}\end{array}$ & $\begin{array}{l}(0.041) \\
-0.048^{* * * *}\end{array}$ & $\begin{array}{l}(0.041) \\
-0.049 * * *\end{array}$ & $\begin{array}{l}(0.041) \\
-0.049 * * *\end{array}$ & $\begin{array}{l}(0.041) \\
-0.049 * * *\end{array}$ & $\begin{array}{l}(0.041) \\
-0.050 * * *\end{array}$ & $\begin{array}{l}(0.041) \\
-0.047 * * *\end{array}$ & $\begin{array}{l}(0.041) \\
-0.048^{* * *}\end{array}$ & $-0.048^{* * *}$ \\
\hline $\begin{array}{l}\text { In(TFP) } \\
\text { Tariffs }\end{array}$ & $\begin{array}{l}(0.007) \\
-0.019 \\
(0.279)\end{array}$ & $\begin{array}{l}(0.007) \\
-0.016 \\
(0.282)\end{array}$ & $\begin{array}{l}(0.008) \\
0.055 \\
(0.298)\end{array}$ & $\begin{array}{l}(0.008) \\
-0.285 \\
(0.293)\end{array}$ & $\begin{array}{l}(0.008) \\
-0.024 \\
(0.291)\end{array}$ & $\begin{array}{l}(0.008) \\
-0.007 \\
(0.287)\end{array}$ & $\begin{array}{l}(0.008) \\
-0.068 \\
(0.284)\end{array}$ & $\begin{array}{l}(0.007) \\
-0.002 \\
(0.286)\end{array}$ & $\begin{array}{l}(0.007) \\
-0.014 \\
(0.283)\end{array}$ & $\begin{array}{l}(0.008) \\
-0.121 \\
(0.293)\end{array}$ & $\begin{array}{l}(0.008) \\
0.028 \\
(0.243)\end{array}$ & $\begin{array}{l}(0.008) \\
-0.033 \\
(0.256)\end{array}$ & $\begin{array}{l}(0.008) \\
-0.043 \\
(0.289)\end{array}$ & $\begin{array}{l}(0.008) \\
0.052 \\
(0.188)\end{array}$ & $\begin{array}{l}(0.007) \\
-0.137 \\
(0.299)\end{array}$ & $\begin{array}{l}(0.008) \\
-0.048 \\
(0.317)\end{array}$ & $\begin{array}{l}(0.008) \\
-0.012 \\
(0.287)\end{array}$ \\
\hline Observations & 122,836 & 122,836 & 122,836 & 122,836 & 122,836 & 122,836 & 122,836 & 122,836 & 122,836 & 122,836 & 122,836 & 122,836 & 122,836 & 122,836 & 122,836 & 122,836 & 122,836 \\
\hline R-squared & 0.250 & 0.250 & 0.250 & 0.250 & 0.250 & 0.249 & 0.249 & 0.250 & 0.250 & 0.249 & 0.249 & 0.250 & 0.250 & 0.250 & 0.249 & 0.249 & 0.249 \\
\hline
\end{tabular}


Table A5. Offshoring and Institutions, 1997-2005. Lagged covariates and dynamic panel data models.

\begin{tabular}{|c|c|c|c|c|c|c|}
\hline & OLS & OLS & $\begin{array}{l}\text { Heckman } \\
\text { Target }\end{array}$ & $\begin{array}{l}\text { Heckman } \\
\text { Target }\end{array}$ & $\begin{array}{l}\text { System } \\
\text { GMM }^{(a)}\end{array}$ & $\begin{array}{l}\text { System } \\
\text { GMM }^{\text {(a) }}\end{array}$ \\
\hline Unweighted index: Inst $_{c t-1}$ & $\begin{array}{l}0.094 \\
(0.159)\end{array}$ & & $\begin{array}{l}0.067 \\
(0.169)\end{array}$ & & $\begin{array}{l}-0.090 \\
(0.826)\end{array}$ & \\
\hline $\begin{array}{l}\text { Unweighted index } \\
\text { interaction: } z_{j} \text { Inst }_{c t-1}\end{array}$ & $\begin{array}{l}0.103 \\
(0.042)^{* *}\end{array}$ & & $\begin{array}{l}0.170 \\
(0.051)^{* * *}\end{array}$ & & $\begin{array}{l}-0.760 \\
(0.548)\end{array}$ & \\
\hline Factor index: Inst $_{c t-1}$ & & $\begin{array}{l}-0.738 \\
(0.201)^{* * *}\end{array}$ & & $\begin{array}{l}-0.530 \\
(0.215)^{* *}\end{array}$ & & $\begin{array}{l}0.784 \\
(2.498)\end{array}$ \\
\hline $\begin{array}{l}\text { Factor index interaction: } \\
z_{j} I_{\text {Inst }}{ }_{c t-1}\end{array}$ & & $\begin{array}{l}0.767 \\
(0.265)^{* * *}\end{array}$ & & $\begin{array}{l}0.949 \\
(0.284)^{* * *}\end{array}$ & & $\begin{array}{l}-1.841 \\
(3.845)\end{array}$ \\
\hline Full set of control variables & yes & yes & yes & yes & yes & yes \\
\hline$R^{2}$ & 0.25 & 0.25 & & & & \\
\hline Observations & 102,480 & 102,480 & 102,399 & 102,399 & 42,531 & 42,531 \\
\hline $\begin{array}{l}\text { AR(1) } \\
\text { AR(2) } \\
\text { Hansen test }\end{array}$ & & & & & $\begin{array}{l}0.011 \\
0.090 \\
0.766\end{array}$ & $\begin{array}{l}0.001 \\
0.289 \\
0.250\end{array}$ \\
\hline
\end{tabular}

Notes: The dependent variable is log offshoring in the OLS estimations and offshoring in levels in the Heckman estimations. Robust standard errors are presented within parenthesis, clustered by country. ${ }^{* * *}$, and ${ }^{* * *}$ indicate significance at the 10,5, and 1 percent levels, respectively. All estimations include country, industry (2-digit), and year fixed effects. Additional exclusion restriction variables in the Heckman estimations are Share of skilled labor and Firm export ratio. Additional control variables not shown are distance, log GDP, population, tariffs, $\log$ TFP, MNE dummy, and log firm size.

(a) The IV matrix in the system GMM estimations is reduced using the collapse and principal component option. Test for serial correlation suggests the inclusion of lags 1-3 of the dependent variable. AR (1) and AR (2) test for first- and second-order autocorrelation (reported p-values). Hansen is a test for over identifying restrictions (reported p-values). 
Table A6. Country List.

\begin{tabular}{|c|c|c|}
\hline & & \\
\hline ALBANIA & HONDURAS & OMAN \\
\hline ALGERIA & INDIA & PAKISTAN \\
\hline ARAB EMIRATES, UNITED & INDONESIA & PANAMA \\
\hline ARGENTINA & IRAN & PAPUA NEW GUINEA \\
\hline AUSTRALIA & IRELAND & PARAGUAY \\
\hline BANGLADESH & ISRAEL & PERU \\
\hline BELGIUM & SIERRA LEONE & POLAND \\
\hline BENIN & ITALY & PORTUGAL \\
\hline BOLIVIA & JAMAICA & RWANDA \\
\hline BOTSWANA & JAPAN & RUSSIA \\
\hline BRAZIL & JORDAN & SWITZERLAND \\
\hline BULGARIA & CAMEROON & SENEGAL \\
\hline BURUNDI & CANADA & SINGAPORE \\
\hline CENTRAL AFRICAN & KENYA & SLOVAKIA \\
\hline REPUBLIC & CHINA & SLOVENIA \\
\hline CHILE & CONGO & SPAIN \\
\hline COLOMBIA & KOREA, SOUTH & SRI LANKA \\
\hline COSTA RICA & CROATIA & BRITAIN \\
\hline CYPRUS & KUWAIT & SOUTH AFRICA \\
\hline DENMARK & LATVIA & SYRIA, ARAB REPUBLIC \\
\hline DOMINICAN REPUBLIC & LITHUANIA & TANZANIA \\
\hline ECUADOR & MADAGASCAR & CHAD \\
\hline EGYPT & MACEDONIA & THAILAND \\
\hline EL SALVADOR & MALAWI & CZECH REPUBLIC \\
\hline IVORY COAST & MALAYSIA & TOGO \\
\hline ESTONIA & MALI & TRINIDAD AND TOBAGO \\
\hline FIJI & MOROCCO & TUNISIA \\
\hline PHILIPPINES & MAURITIUS & TURKEY \\
\hline FINLAND & MEXICO & GERMANY \\
\hline FRANCE & MOZAMBIQUE & UGANDA \\
\hline GABON & NAMIBIA & UKRAINE \\
\hline GEORGIA & NETHERLANDS & HUNGARY \\
\hline GHANA & NEPAL & URUGUAY \\
\hline GREECE & NICARAGUA & USA \\
\hline GUATEMALA & NIGER & VENEZUELA \\
\hline GUINEA-BISSAU & NIGERIA & VIETNAM \\
\hline \multirow[t]{3}{*}{ GUYANA } & NORWAY & ZAMBIA \\
\hline & NEW ZEALAND & ZIMBABWE \\
\hline & & AUSTRIA \\
\hline
\end{tabular}

